medRxiv preprint doi: https://doi.org/10.1101/2022.03.02.22271753; this version posted March 2, 2022. The copyright holder for this preprint (which was not certified by peer review) is the author/funder, who has granted medRxiv a license to display the preprint in perpetuity.

It is made available under a CC-BY 4.0 International license .

\title{
Non-occupational physical activity and risk of 22 cardiovascular disease, cancer, and mortality outcomes: a dose- response meta-analysis of large prospective studies
}

Leandro Garcia*, Matthew Pearce*, Ali Abbas, Alexander Mok ${ }^{*}$, Tessa Strain ${ }^{*}$, Sara Ali, Alessio Crippa, Paddy C Dempsey, Rajna Golubic, Paul Kelly, Yvonne Laird, Eoin McNamara, Samuel Moore, Thiago Herick de Sa, Andrea D Smith, Katrien Wijndaele, James Woodcock ${ }^{\S}$, Søren Brage ${ }^{\S}$ (https://orcid.org/0000-0002-1265-7355)

\footnotetext{
* These authors contributed equally.

$\S$ These authors contributed equally.
}

MRC Epidemiology Unit, School of Clinical Medicine, University of Cambridge, Cambridge, CB2 OQQ, United Kingdom (Garcia, Pearce, Abbas, Mok, Strain, Dempsey, Golubic, McNamara, Smith, Wijndaele, Woodcock, Brage); Centre for Public Health, School of Medicine, Dentistry and Biomedical Sciences, Queen's University Belfast, Belfast, BT12 6BA, United Kingdom (Garcia); Singapore Institute for Clinical Sciences (SICS), Agency for Science, Technology and Research (A*STAR), 138632, Singapore (Mok); School of Clinical Medicine, University of Cambridge, Cambridge, CB2 OSP, United Kingdom (Ali, Moore); Department of Medical Epidemiology and Biostatistics, Karolinska Institutet, Stockholm, SE-171 77, Sweden (Crippa); Diabetes Research Centre, University of Leicester, Leicester General Hospital, Leicester, LE5 4PW, United Kingdom (Dempsey); Baker Heart \& Diabetes Institute, Melbourne, 3004, Australia (Dempsey); Cambridge University Hospitals NHS Foundation Trust, Addenbrooke's Hospital, Cambridge, CB2 OQQ, United Kingdom (Golubic); Physical Activity for Health Research Centre, Moray House School of Education and Sport, University of Edinburgh, Edinburgh, EH8 8AQ, United Kingdom (Kelly); Prevention Research Collaboration, Sydney School of Public Health, Faculty of Medicine and Health, The University of Sydney, Sydney, 2006, Australia (Laird); Charles Perkins Centre, The University of Sydney, Sydney, 2006, Australia (Laird); Economic and Social Research Institute, Dublin, D02 K138, Ireland (McNamara); Centre for Epidemiological Research in Nutrition and Health, University of Sao Paulo, Sao Paulo, 01246904, Brazil (Sa); Department of Behavioural Science and Health, University College London, London, WC1E 6BT, United Kingdom (Smith). 
medRxiv preprint doi: https://doi.org/10.1101/2022.03.02.22271753; this version posted March 2, 2022. The copyright holder for this preprint (which was not certified by peer review) is the author/funder, who has granted medRxiv a license to display the preprint in perpetuity.

It is made available under a CC-BY 4.0 International license .

\section{Correspondence to:}

Dr Søren Brage

MRC Epidemiology Unit, University of Cambridge, School of Clinical Medicine, Box 285 Institute of Metabolic Science,

Cambridge Biomedical Campus, Cambridge, CB2 0QQ, United Kingdom

E-mail: Soren.brage@mrc-epid.cam.ac.uk 
medRxiv preprint doi: https://doi.org/10.1101/2022.03.02.22271753; this version posted March 2, 2022. The copyright holder for this preprint (which was not certified by peer review) is the author/funder, who has granted medRxiv a license to display the preprint in perpetuity.

It is made available under a CC-BY 4.0 International license .

\section{ABSTRACT}

Objective: To estimate dose-response associations between non-occupational physical activity and multiple chronic disease outcomes in the general adult population.

Eligibility criteria: Prospective cohort studies with (a) general population samples $>10,000$ adults, (b) $\geq 3$ exposure categories, and (c) risk measures and confidence intervals for all-cause mortality, total cardiovascular disease, coronary heart disease, stroke, heart failure, total cancer, and site-specific cancers (head and neck, myeloid leukemia, myeloma, gastric cardia, lung, liver, endometrium, colon, breast, bladder, rectum, esophagus, prostate, kidney).

Information sources: PubMed, Scopus, Web of Science, and reference lists of published studies, searched in February 2019.

Data extraction and synthesis: Independent extraction and double-checking of study characteristics, exposure, and outcome assessment by two reviewers for each paper. Primary exposure was non-occupational physical activity volume, harmonized to physical activity energy expenditure in marginal MET-hours per week (mMET-h/week). The current minimum recommendations for physical activity (150 $\mathrm{min} /$ week of moderate-to-vigorous physical activity) equate to $8.75 \mathrm{mMET}-\mathrm{h} /$ week. Outcomes were risks of mortality, cardiovascular diseases, and cancers. We used restricted cubic splines in random-effects meta-analyses. Potential population impact was quantified using impact fractions.

Results: 196 articles were included, covering 94 cohorts. The evidence base was largest for all-cause mortality (50 independent results; 163,415,543 person-years; 811,616 events), and incidence of cardiovascular disease (37 independent results; $28,884,209$ person-years; 74,757 events) and cancer (31 independent results; 35,500,867 personyears; 185,870 events). In general, inverse non-linear associations were observed, steeper between 0 and 8.75 mMET$\mathrm{h} /$ week, with smaller marginal reductions in risk above this level to $17.5 \mathrm{mMET}-\mathrm{h} /$ week, beyond which additional reductions were small and uncertain. Associations were stronger for all-cause and cardiovascular disease mortality than for cancer mortality. If all insufficiently active individuals had met the recommended physical activity level, $15.7 \%$ (95\% Cl: 13.1 to $18.2 \%)$ of all premature deaths would have been averted.

Conclusions: Inverse non-linear dose-response associations suggest substantial protection against a range of chronic disease outcomes from small increases in non-occupational physical activity in inactive adults.

Review registration: PROSPERO CRD42018095481. 
medRxiv preprint doi: https://doi.org/10.1101/2022.03.02.22271753; this version posted March 2, 2022. The copyright holder for this preprint (which was not certified by peer review) is the author/funder, who has granted medRxiv a license to display the preprint in perpetuity.

It is made available under a CC-BY 4.0 International license .

\section{INTRODUCTION}

Cardiovascular disease (CVD) is the leading cause of death globally, responsible for 17.9 million annual deaths in $2019,{ }^{1}$ whereas cancers top the global disease burden with respect to disability-adjusted life-years. ${ }^{2}$ The relative contribution of each risk and protective factor to the incidence of, and mortality from, these conditions is an ongoing debate.

Higher levels of physical activity (PA) have been associated with lower rates of premature mortality and chronic disease outcomes. ${ }^{3}$ However, the shape of the dose-response association has been more difficult to determine, and is yet to be established for a range of diseases. One reason is that more data are needed to examine a wide enough exposure range and less common outcomes; another is that large population studies use a variety of instruments to assess PA. While this makes the task of conducting a dose-response meta-analysis harder, it is possible through exposure harmonization. 4

Accurate estimation of the dose-response association between PA and disease outcomes, combined with prevalence estimates, is a prerequisite for assessing the population disease burden of insufficient PA and the potential impact of changes to population levels of PA. Modelling studies that estimate the impact of these strategies have found that the shape of the dose-response association makes a significant difference when quantifying population health impacts. ${ }^{6}$

Pooled analyses of the association between leisure-time PA and mortality have been undertaken in six US studies, showing an inverse, curvilinear dose-response association, ${ }^{7}$ but the totality of evidence has not recently been assessed. For cancer and CVD outcomes, the Global Burden of Disease (GBD) Study reported non-linear dose-response associations for total PA (i.e., including physical activity performed du ring work, or occupational activity), estimating that a dose above $65 \mathrm{MET}-\mathrm{h} /$ week is associated with a $20 \%$ risk reduction. ${ }^{5}$ The occupational component of PA is often crudely measured via self-report or not measured at all and there is some evidence that it might have a different relation to health endpoints compared with leisure-time $P A .^{8-10}$

Using extensive exposure harmonization to quantify non-occupational PA, we therefore examined the doseresponse association between non-occupational PA and the risk of $22 \mathrm{CVD}$, cancer, and mortality outcomes. To contextualize our results for public health promotion, we used potential population impact fractions to estimate the proportion of preventable deaths and disease outcomes at different non-occupational PA levels. 
medRxiv preprint doi: https://doi.org/10.1101/2022.03.02.22271753; this version posted March 2, 2022. The copyright holder for this preprint (which was not certified by peer review) is the author/funder, who has granted medRxiv a license to display the preprint in perpetuity.

It is made available under a CC-BY 4.0 International license .

\section{METHODS}

The study protocol is available at PROSPERO, registration number CRD42018095481.

\subsection{Eligibility criteria}

Supplementary eMethods 1 shows the study inclusion and exclusion criteria. We included prospective cohort studies that followed adults ( $\geq 18$ years) without pre-existing conditions, reported PA at baseline in at least three ordinal exposure levels, and reported risk estimates for the examined outcomes. We excluded studies with $<10,000$ participants (to limit potential bias from small study sizes with positive results) or if the follow-up period was $<3$ years (to minimize reverse causality bias).

Only articles that examined leisure-time PA, alone or in combination with other domains or specific types of activity, were included. We excluded articles whose measures of PA contained occupational activity that could not be factored out, and that investigated individual domains of PA that did not include leisure-time activity (e.g., transportrelated physical activity only).

The outcomes of interest were:

- All-cause, total CVD, and total cancer mortality;

- Total CVD, coronary heart disease, stroke, and heart failure incidence (fatal and non-fatal);

- Total and site-specific (head and neck, myeloid leukemia, myeloma, gastric cardia, lung, liver, endometrial, colon, breast, bladder, rectum, esophageal, prostate, and kidney) cancer incidence (fatal and non-fatal). These site-specific cancers were selected based on previously reported associations with PA. ${ }^{11}$

\subsection{Search and selection process}

We searched PubMed, Scopus, Web of Science, and reference lists of reviews retrieved from our systematic review, known to the authors, or cited in the 2018 U.S. Physical Activity Guidelines Advisory Committee Scientific Report. ${ }^{12}$ The Supplement (eMethods 2) details the systematic search strategy. We considered peer-reviewed articles in any language published in academic journals until February 2019.

Titles and abstracts and, subsequently, full texts were screened independently twice for eligibility (Supplement, eFigure1). Disagreements were resolved by discussion.

If multiple articles reported results on the same cohort and outcome, we followed specific criteria (eMethods 3) to select one.

\subsection{Data extraction}


medRxiv preprint doi: https://doi.org/10.1101/2022.03.02.22271753; this version posted March 2, 2022. The copyright holder for this preprint (which was not certified by peer review) is the author/funder, who has granted medRxiv a license to display the preprint in perpetuity.

It is made available under a CC-BY 4.0 International license .

Data from each paper were extracted by one reviewer and double-checked independently by a second reviewer. Disagreements were checked against the full text and resolved by discussion.

We extracted data on publication (first author, year of publication), study characteristics (country, cohort name, sample size, age and sex of participants, and duration of follow-up), PA exposure assessment (instrument, domains of activity, and exposure categories), and outcome assessment. We also identified how original study analyses had considered baseline morbidity (exclusion at baseline or statistical adjustment in multivariable regression models) and early incident cases during follow-up.

For each exposure category, we extracted information to quantify PA volume, number of cases, number of participants and/or person-years of follow-up, and risk estimates with $95 \%$ confidence intervals ( $95 \% \mathrm{Cls})$. Risk estimates from the most adjusted model were used. When available, risk estimates of the most adjusted model without adiposity-related covariates (e.g., BMI, waist circumference) were retrieved and used in sensitivity analyses. Results reported separately by sex or other attributes (e.g., age, ethnicity) or for multiple cohorts within an article were treated as separate associations. When necessary, data were obta ined from other publications using the same cohort, imputation procedures (Supplement, eMethods 4), or by contacting authors.

\subsection{Physical activity exposure harmonization}

\subsubsection{Overview of harmonization}

We harmonized reported PA exposure levels from all included studies into a common metric of nonoccupational PA volume in marginal MET-hours per week (mMET-h/week), reflecting the rate of energy expenditure outside of work, above the resting metabolic rate (1 MET). This allows correct equating of PA volume of time spent at different PA intensity levels. ${ }^{4}$ The principles of each aspect of our comprehensive harmonization procedure are described below and presented in a flowchart available in our OSF repository. The last columns of the "Details of included articles and original and harmonized exposures" table in the same OSF repository contain the details of how the original PA exposure categories of each study were harmonized to mMET-h/week.

\subsubsection{Frequency, duration, and intensity assumptions}

Studies that described PA exposure as frequency and/or duration were converted to weekly duration. If session duration was not provided, we assumed a duration of 0.75 hour/session ( 0.5 hour/session in sensitivity analyses). Studies reporting categorical frequency data (e.g., never, sometimes, and often) were converted to weekly duration using assumptions for both frequency (e.g., 0, 2, 5 sessions per week) and duration of sessions. When PA intensity was 
medRxiv preprint doi: https://doi.org/10.1101/2022.03.02.22271753; this version posted March 2, 2022. The copyright holder for this preprint (which was not certified by peer review) is the author/funder, who has granted medRxiv a license to display the preprint in perpetuity.

It is made available under a CC-BY 4.0 International license .

not explicitly described, we considered the reported activities as light, moderate, or vigorous based on the description and using the Compendium of Physical Activities. ${ }^{13}$ We assigned mMET values of 1.5 for light, 3.5 for moderate and moderate-to-vigorous, and 7.0 for vigorous PA (1 mMET less in sensitivity analyses).

\subsubsection{Converting absolute energy expenditure to MET values}

For studies reporting energy expenditure without adjustment for body weight (e.g., kJ/day, kcal/week), energy expenditure was divided by reported weights to derive MET equivalents ( $1 \mathrm{MET}=1 \mathrm{kcal} / \mathrm{kg} / \mathrm{hour}$ ). If unavailable, body weight was calculated from reported BMI and height. If BMI was reported without height, a mean value from national survey data was used for height.

\subsubsection{Subtracting resting energy expenditure from estimates of $P A$}

To marginalize studies reporting volume of PA in gross units, 1 MET-h was subtracted for each hour of activity. If mean duration was not available, we used a conversion equation derived from all remaining studies where both volume and duration were available (Supplement, eMethods 5).

\subsubsection{Isolating the non-occupational component of aggregate PA estimates}

Some articles provided aggregated exposures of non-occupational and occupational PA alongside other behaviors, such as sleep or sedentary time. When quantified information about these behaviors was available, this was subtracted from the point estimate of each exposure category. If no quantifiable data were available, we assumed occupational activity to be 40 hours/week at $1.25 \mathrm{MET}$ (or $0.25 \mathrm{mMET}$ ) or the value of the lowest exposure category and subtracted this from all exposure categories.

\subsection{Meta-analytic methods}

We conducted meta-analysis for any exposure-outcome pair with at least four independent results. Where necessary, risk estimates were re-calculated to set the least active category as the referent. ${ }^{14}$ For studies reporting only stratified results (e.g., sex or ethnicity), we combined stratum-specific risks into overall population estimates using fixed-effect meta-analysis.

We performed a two-stage random-effects meta-a nalysis. In the first stage, we estimated the study-specific associations using generalized least squares to incorporate the correlation within each set of log-relative risks. ${ }^{15,16}$ In the second stage, we estimated the pooled association by combining study-specific dose-response coefficients using 
medRxiv preprint doi: https://doi.org/10.1101/2022.03.02.22271753; this version posted March 2, 2022. The copyright holder for this preprint (which was not certified by peer review) is the author/funder, who has granted medRxiv a license to display the preprint in perpetuity.

It is made available under a CC-BY 4.0 International license .

restricted maximum likelihood. ${ }^{17,18}$ We assumed non-linearity of dose-response associations, ${ }^{4,5,7,19-21}$ and thus modelled them by fitting restricted cubic splines. Given that the volume of PA reported in most studies were at the lower end of the exposure range and that there is greater uncertainty about reliability of very high levels of selfreported PA, we set three knots at the $0^{\text {th }}, 37.5^{\text {th }}$, and $75^{\text {th }}$ percentiles of person-years rather than persons $\left(0^{\text {th }}, 42.5^{\text {th }}\right.$ and $85^{\text {th }}$ percentiles in sensitivity analyses). The slope was fixed at the last knot. If the statistical model was unable to converge, we progressively increased the percentile for the upper knot by one percent until model convergence.

To investigate the potential effect of study-level confounders on the pooled results across outcomes, we conducted subgroup analyses with the 11 studies that reported results for all all-cause, CVD, and cancer mortality outcomes and contrasted them with results from the corresponding main analysis. We also conducted subgroup analysis by sex using studies that reported separate results for men and women.

\subsection{Estimation of population health impact}

Potential population impact fractions (PIFs) were calculated for all outcomes based on PA exposure levels in the population of all included cohorts for a given outcome. ${ }^{22}$ PIFs were calculated for three exposure levels based on the World Health Organization PA recommendations for adults ${ }^{23}: 8.75 \mathrm{mMET}-\mathrm{h} /$ week (the minimum recommended level, equivalent to 2.5 hours/week of PA at an intensity of $3.5 \mathrm{mMET}$, such as a brisk walking), $17.5 \mathrm{mMET}$-h/week (upper bound of recommended levels for health benefits), and $4.375 \mathrm{mMET}-\mathrm{h} /$ week (half the minimum recommended level).

\subsection{Risk of bias assessment}

We explored the impact of four potential sources of bias in individual articles and our meta-analytical procedures: how studies had analyzed participants with other morbidities, whether they excluded early incident cases during follow-up, whether imputation procedures for missing data were required, and how we handled exposure harmonization including separation of occupational PA. For each of these we contrasted the overall risk estimates between studies with different characteristics. This was done for the five outcomes with the largest number of independent results (all-cause mortality, and total CVD and cancer mortality and incidence), using a fixed PA level of 8.75 mMET-h/week, relevant to the four sources of bias. 
medRxiv preprint doi: https://doi.org/10.1101/2022.03.02.22271753; this version posted March 2, 2022. The copyright holder for this preprint (which was not certified by peer review) is the author/funder, who has granted medRxiv a license to display the preprint in perpetuity.

It is made available under a CC-BY 4.0 International license .

\subsection{Software, data, and code availability}

Analyses were performed using R, version 4.0.5, and the dosresmeta package, ${ }^{18}$ version 2.0.1. An interactive interface to visualize the dose-response associations was developed using the Shiny package, version 1.0.5. Syntax for all analyses and the interactive interface are available at https://github.com/meta-analyses/.

\subsection{Patient and public involvement}

Patients and the public were not involved in the development of this work.

\section{RESULTS}

\subsection{Identified literature}

A total of 196 articles $^{7,24-218}$ were included (Supplement, eFigure 1), covering 94 cohorts and 330 independent results. The evidence base was largest for all-cause mortality (50 independent results; $163,415,543$ person-years, 811,616 events), total CVD incidence (37 independent results; 28,884,209 person-years, 74,757 events), and total cancer incidence (31 independent results; 35,500,867 person-years, 185,870 events). Details of all selected articles can be found in our OSF repository and data underlying each of the dose-response estimation can be downloaded at https://shiny.mrc-epid.cam.ac.uk/meta-analyses-physical-activity/.

\subsection{Primary dose-response analyses}

Most study participants reported non-occupational PA levels below 17.5 mMET-h/week (76\% of person-years), with almost all data below $35 \mathrm{mMET}-\mathrm{h} /$ week (94\% of person-years). Figure 1 shows the exposure distribution for the cohorts included in the all-cause mortality analysis. Inverse, curvilinear dose-response associations between PA and most outcomes were observed, with stronger associations at lower volumes of PA. In most cases, diminishing reductions in risk and increasing uncertainty were observed at high PA volumes, particularly beyond 17.5 mMETh/week. Interactive dose-response curves and the exposure distributions are available at https://shiny.mrc-

\section{epid.cam.ac.uk/meta-analyses-physical-activity/.}

The association was stronger and more curvilinear for all-cause and CVD mortality than for cancer mortality

(Figure 2, Table 1). Compared to inactive individuals, adults accumulating $8.75 \mathrm{mMET}-\mathrm{h} /$ week had $31 \%$ (95\% $\mathrm{Cl}: 27$ to $35 \%$ ) and $29 \%$ (95\% Cl: 23 to 34\%) lower risk of all-cause and CVD mortality, respectively, whereas the risk reduction for total cancer mortality was $15 \%(95 \% \mathrm{Cl}: 11$ to $19 \%)$. 
medRxiv preprint doi: https://doi.org/10.1101/2022.03.02.22271753; this version posted March 2, 2022. The copyright holder for this preprint (which was not certified by peer review) is the author/funder, who has granted medRxiv a license to display the preprint in perpetuity.

It is made available under a CC-BY 4.0 International license.

A strong curvilinear association was observed for total CVD incidence (27\% lower risk [95\% Cl: 21 to $31 \%$ ] at 8.75 mMET-h/week). However, associations were weaker and more linear for the incidence of specific CVD outcomes (coronary heart disease, heart failure, and stroke), with the strongest association observed for coronary heart disease (21\% lower risk [95\% Cl: 16 to $26 \%$ ] at $8.75 \mathrm{mMET}-\mathrm{h} /$ week) (Figure 3, Table 1).

The association was weaker and more linear for total cancer incidence (12\% lower risk [95\% Cl: 8 to $15 \%]$ at 8.75 mMET-h/week). For the incidence of site-specific cancers, curvilinear and stronger associations were observed for head and neck, myeloid leukemia, myeloma, and gastric cardia (35 to 22\% lower risk at $8.75 \mathrm{mMET}$-h/week). Weaker and more linear associations were observed for lung, liver, endometrial, colon, and breast (16 to $5 \%$ lower risk at 8.75 mMET-h/week). Non-significant associations were observed for bladder, esophageal, prostate, and rectal cancer

(Figure 4, Table 1). No eligible studies were available for malignant melanoma.

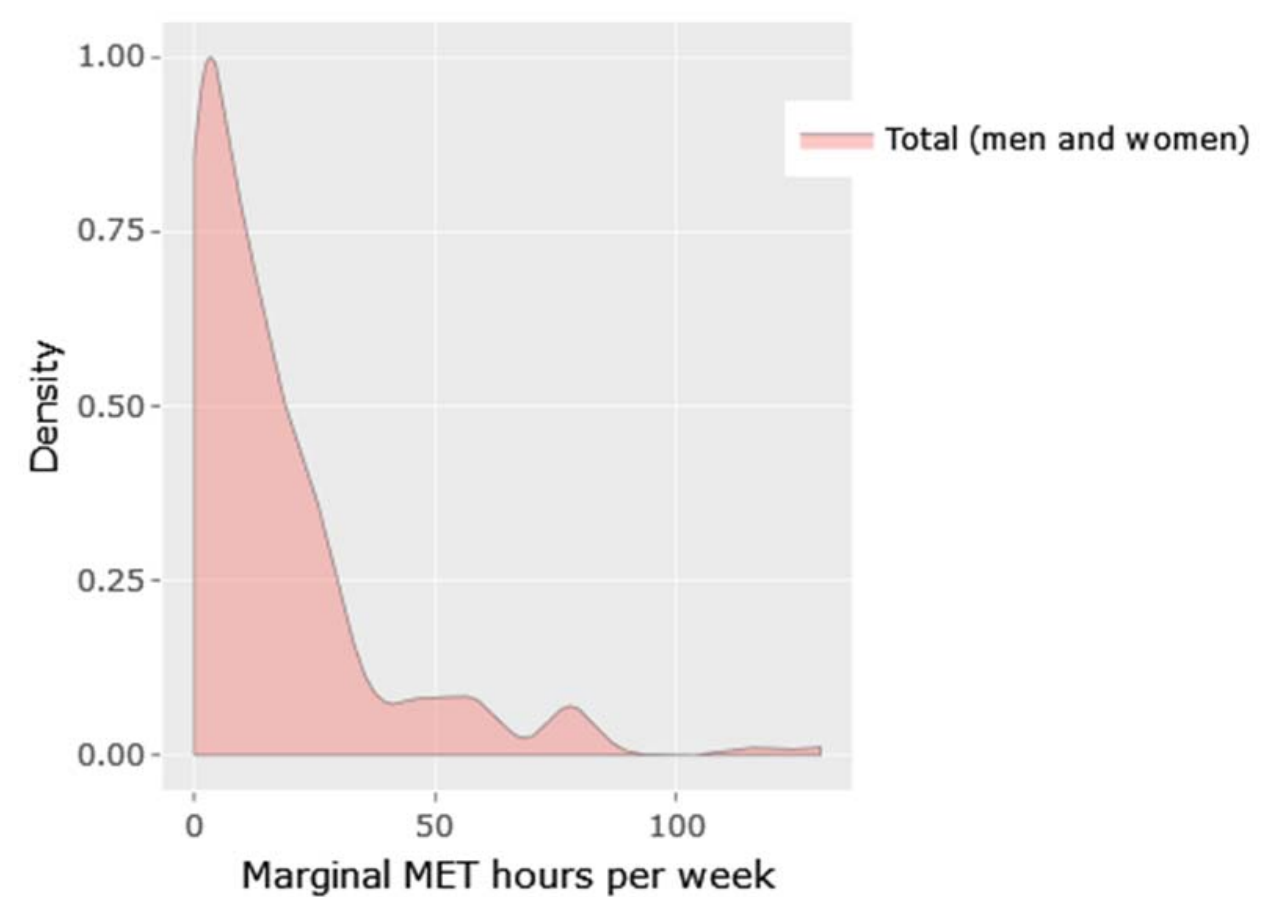

\begin{tabular}{|c|c|c|c|c|c|}
\hline Minimum & $\mathbf{2 5}^{\text {th }}$ percentile & Median & Mean & $\mathbf{7 5}^{\text {th }}$ percentile & Maximum \\
\hline 0.0 & 2.4 & 10.5 & 16.9 & 22.5 & 130.0 \\
\hline
\end{tabular}

Figure 1. Distribution of marginal MET hours per week for cohorts included in the all-cause mortality analysis. Exposure distribution for cohorts included in the analysis of other outcomes are available at https://shiny.mrcepid.cam.ac.uk/meta-analyses-physical-activity/. 
medRxiv preprint doi: https://doi.org/10.1101/2022.03.02.22271753; this version posted March 2, 2022. The copyright holder for this preprint (which was not certified by peer review) is the author/funder, who has granted medRxiv a license to display the preprint in perpetuity.

\section{It is made available under a CC-BY 4.0 International license .}

\section{All-cause mortality}

Number of entries: 50 \& Person-years: 163,415,543

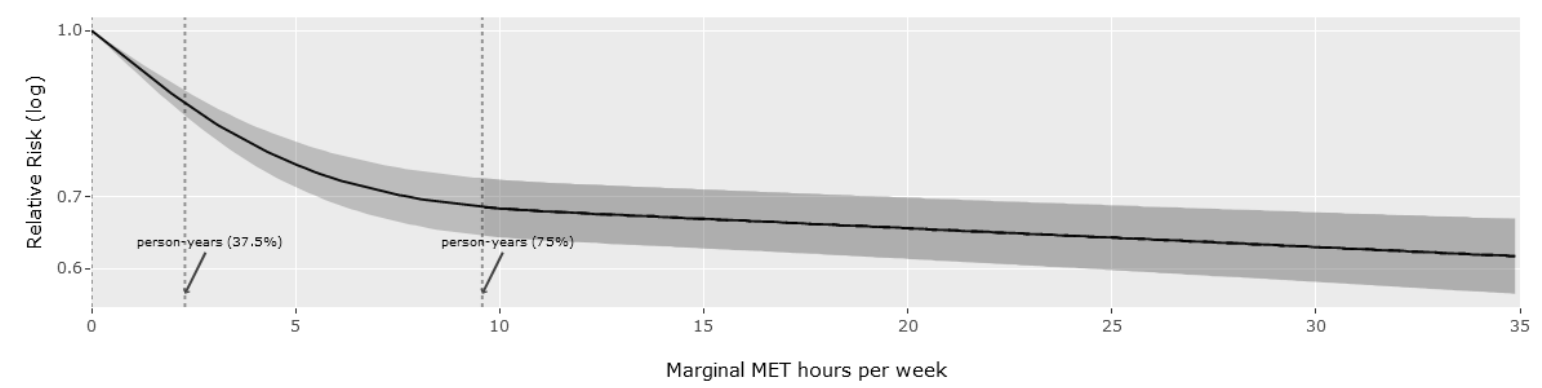

\section{Cardiovascular disease mortality}

Number of entries: 29 \& Person-years: 25,886,430

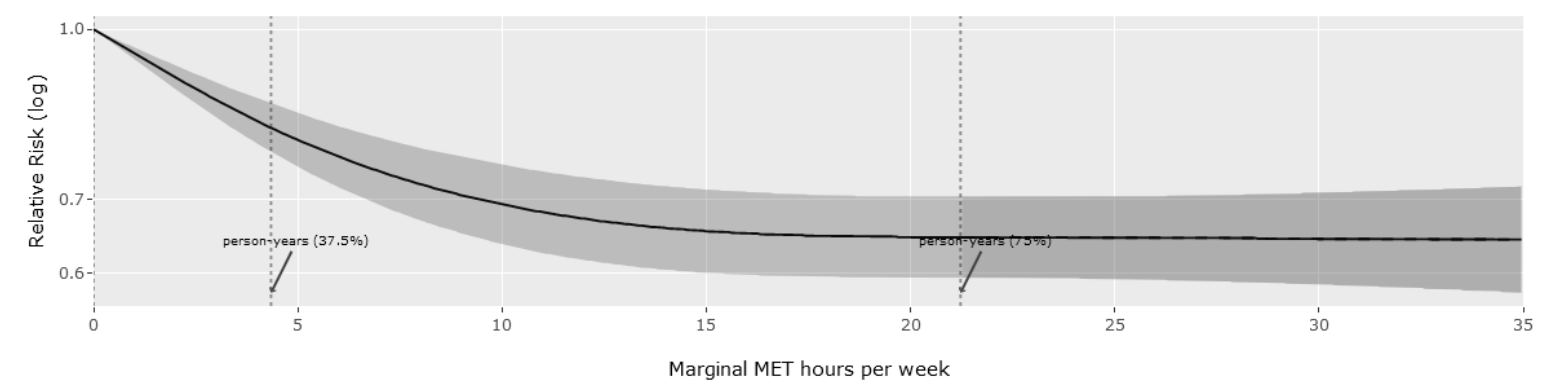

\section{Cancer mortality}

Number of entries: 24 \& Person-years: 24,077,682

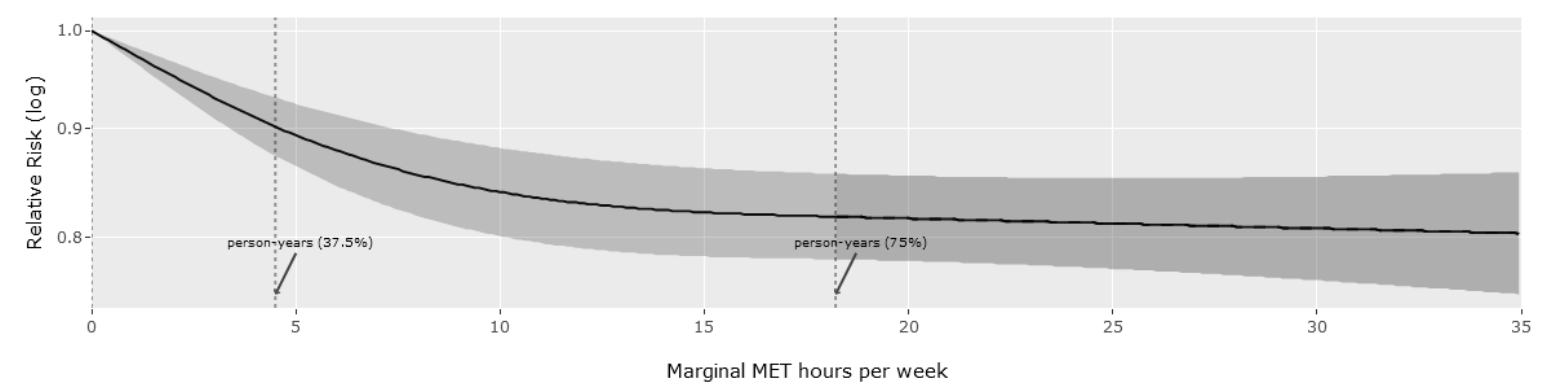

Figure 2. Dose-response association between non-occupational physical activity and mortality outcomes. Vertical dashed lines: cubic spline knots $\left(0^{\text {th }}, 37.5^{\text {th }}\right.$, and $75^{\text {th }}$ percentile of person-years) Dark grey area beyond upper knot: constrained to be linear. 
medRxiv preprint doi: https://doi.org/10.1101/2022.03.02.22271753; this version posted March 2, 2022. The copyright holder for this preprint (which was not certified by peer review) is the author/funder, who has granted medRxiv a license to display the preprint in perpetuity.

\section{It is made available under a CC-BY 4.0 International license .}

\section{Total cardiovascular disease}

Number of entries: 37 \& Person-years: 28,884,209

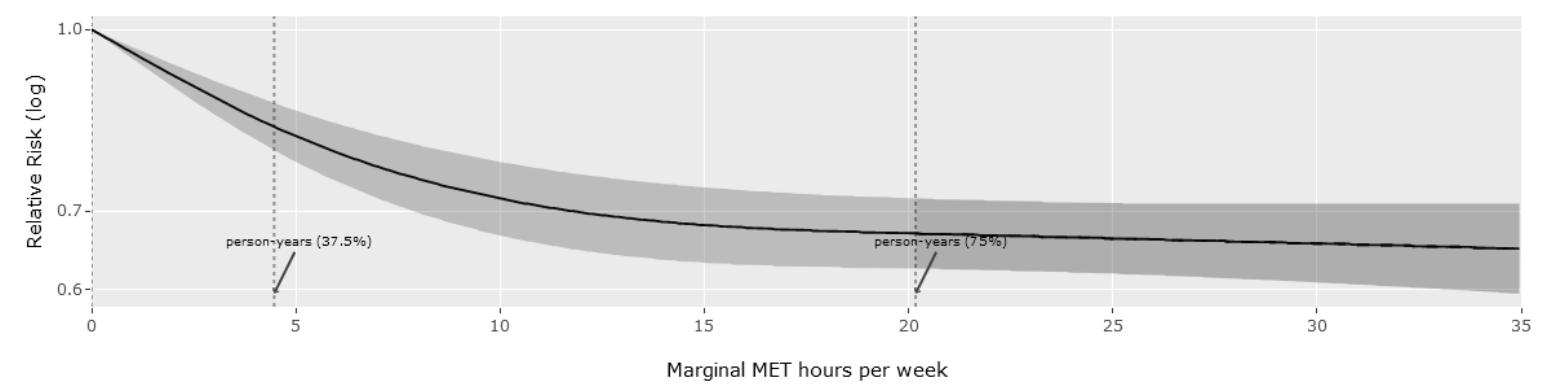

\section{Coronary heart disease}

Number of entries: 26 \& Person-years: 29,071,019

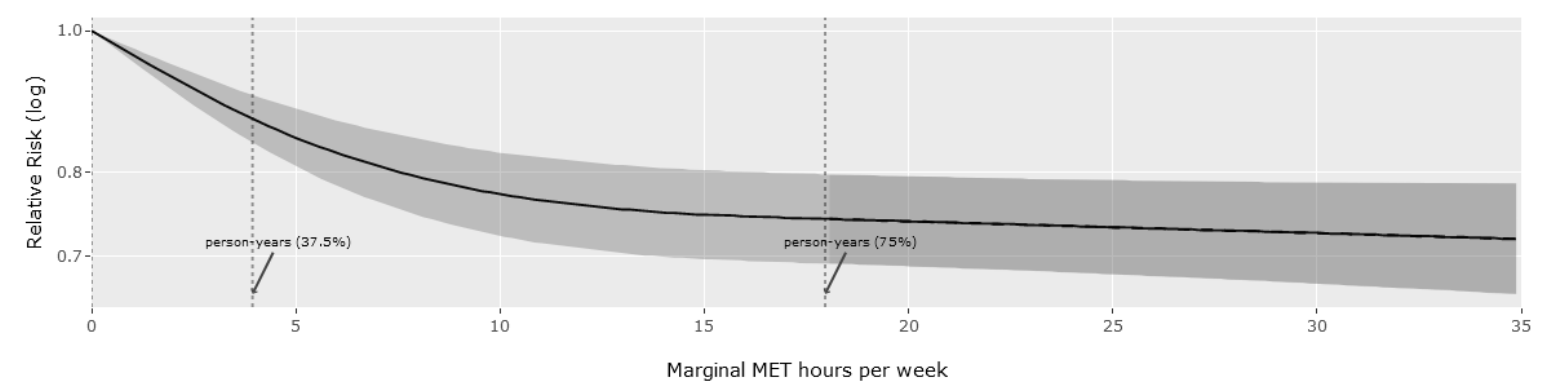

\section{Stroke}

Number of entries: 25 \& Person-years: 24,490,541

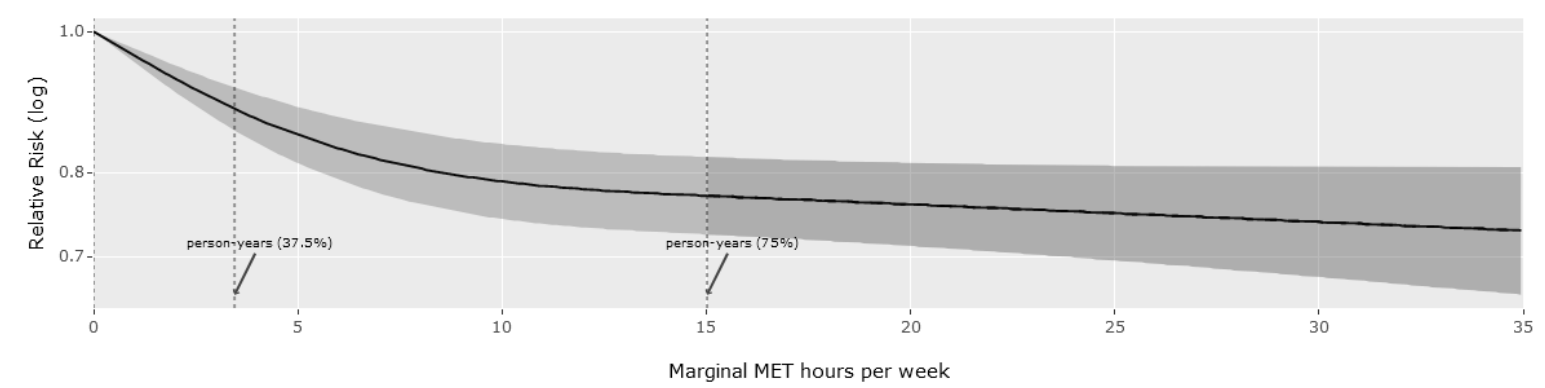

\section{Heart failure}

Number of entries: 11 \& Person-years: 6,088,292

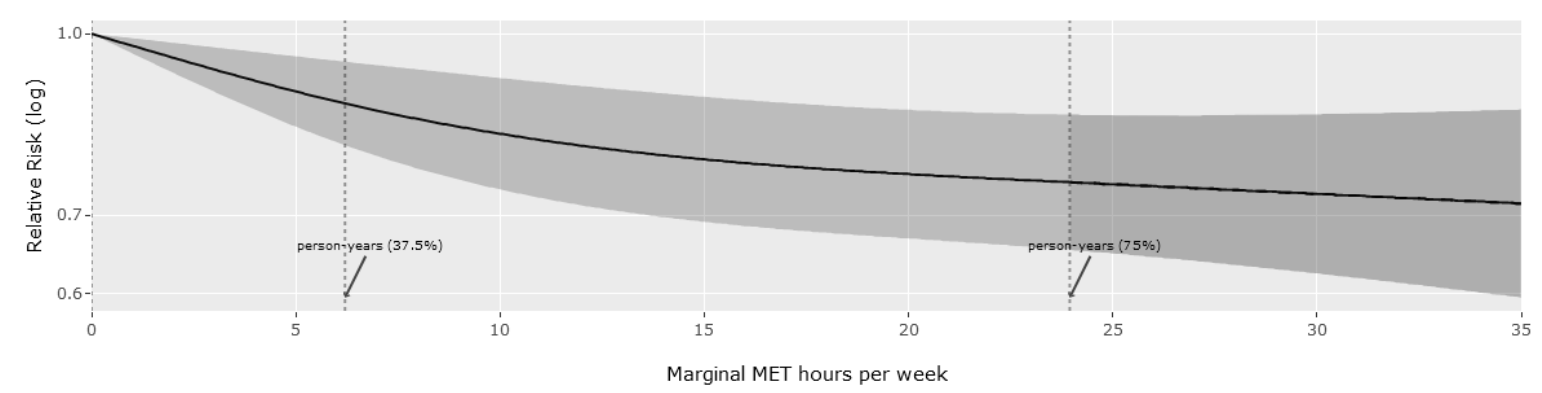

Figure 3. Dose-response association between non-occupational physical activity and incidence of cardiovascular diseases. Vertical dashed lines: cubic spline knots $\left(0^{\text {th }}, 37.5^{\text {th }}\right.$, and $75^{\text {th }}$ percentile of person-years) Dark grey area beyond upper knot: constrained to be linear. 
medRxiv preprint doi: https://doi.org/10.1101/2022.03.02.22271753; this version posted March 2, 2022. The copyright holder for this preprint (which was not certified by peer review) is the author/funder, who has granted medRxiv a license to display the preprint in perpetuity.

\section{It is made available under a CC-BY 4.0 International license .}

\section{Total cancer}

Number of entries: 31 \& Person-years: 35,500,869

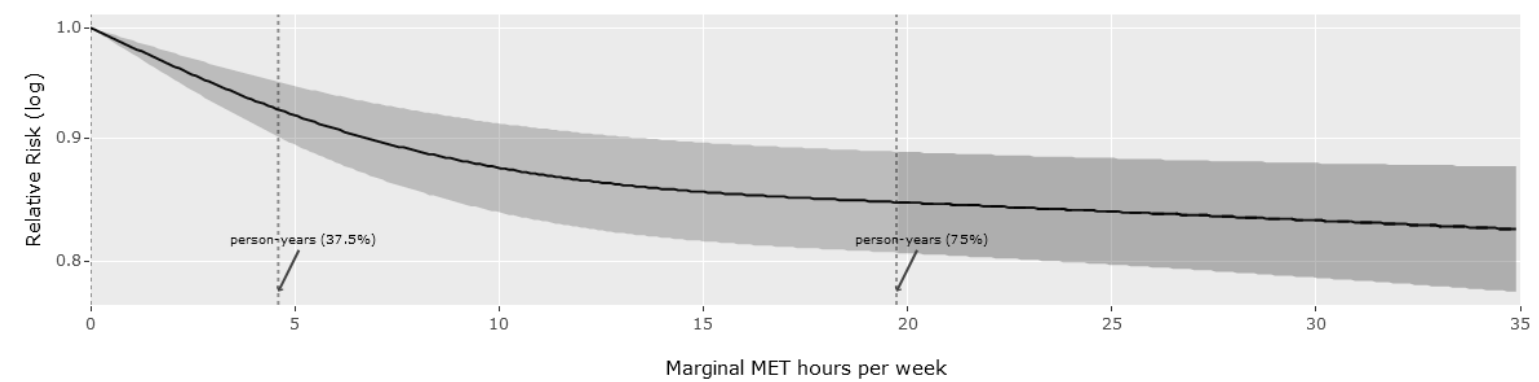

\section{Head and neck cancer}

Number of entries: 4 \& Person-years: 7,332,091

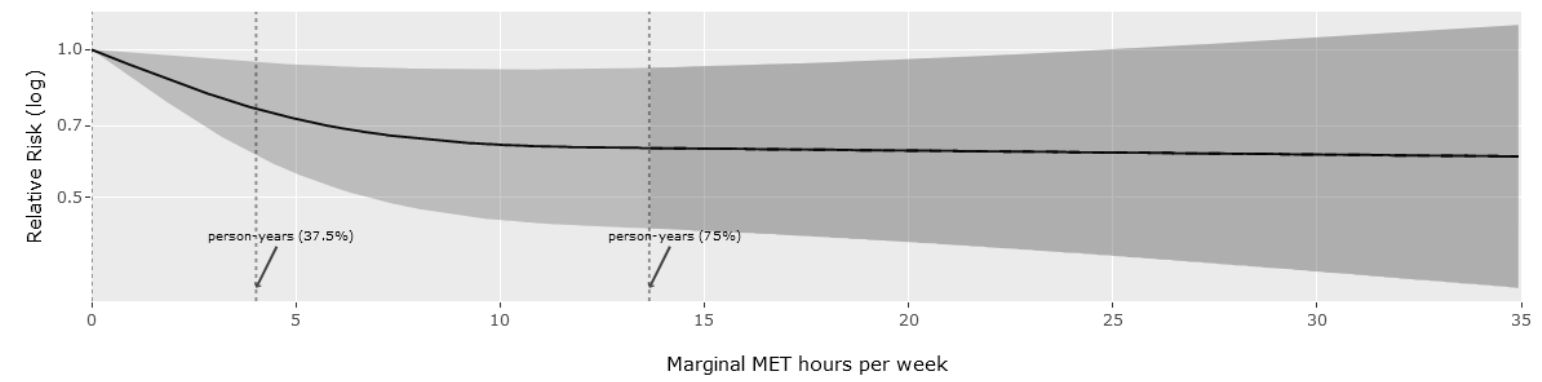

\section{Myeloid leukaemia}

Number of entries: 4 \& Person-years: 9,491,850

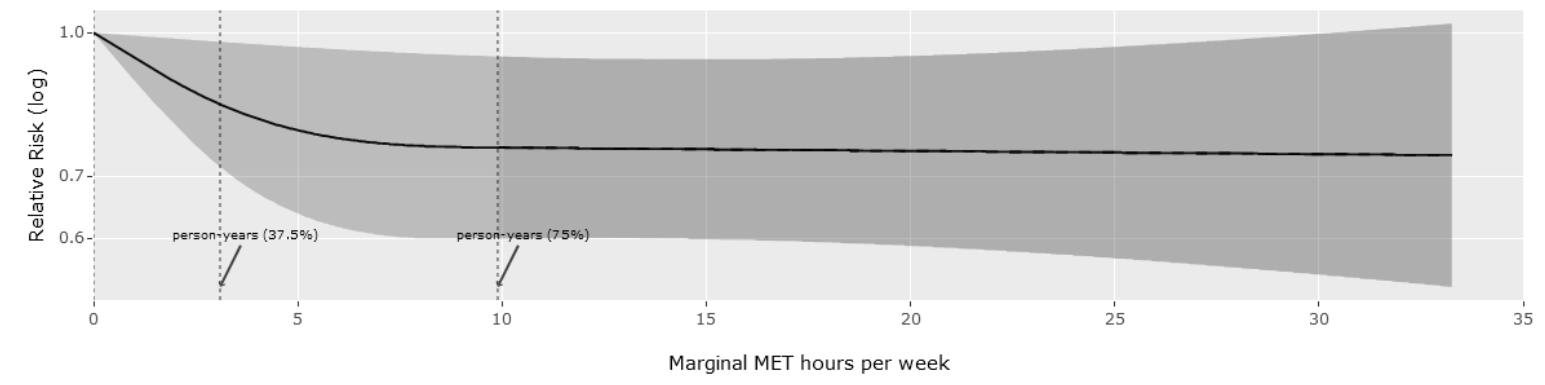

\section{Myeloma}

Number of entries: 4 \& Person-years: 11,335,821

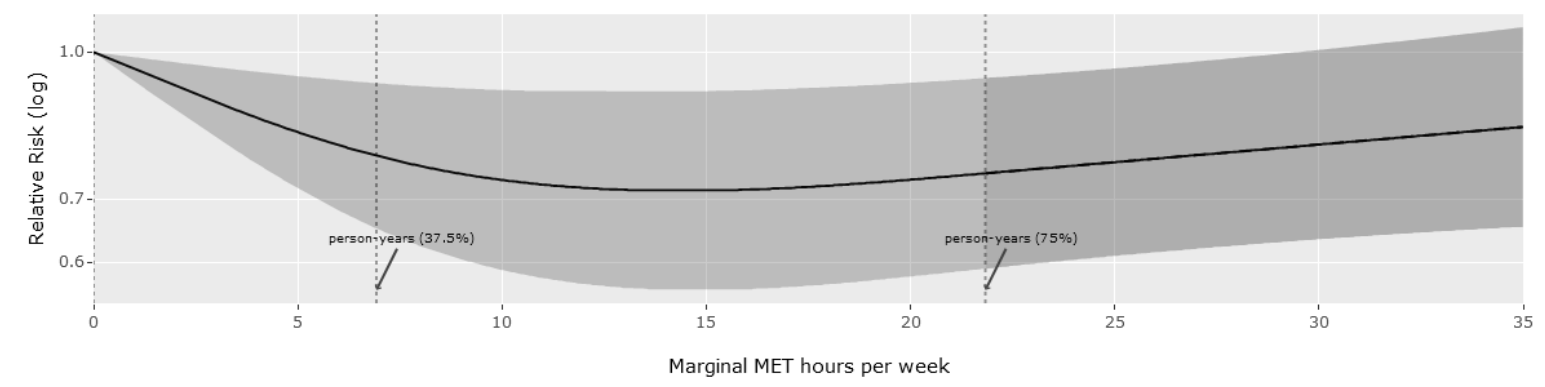


medRxiv preprint doi: https://doi.org/10.1101/2022.03.02.22271753; this version posted March 2, 2022. The copyright holder for this preprint (which was not certified by peer review) is the author/funder, who has granted medRxiv a license to display the preprint in perpetuity.

\section{It is made available under a CC-BY 4.0 International license .}

\section{Gastric cardia cancer}

Number of entries: 5 \& Person-years: 9,647,534

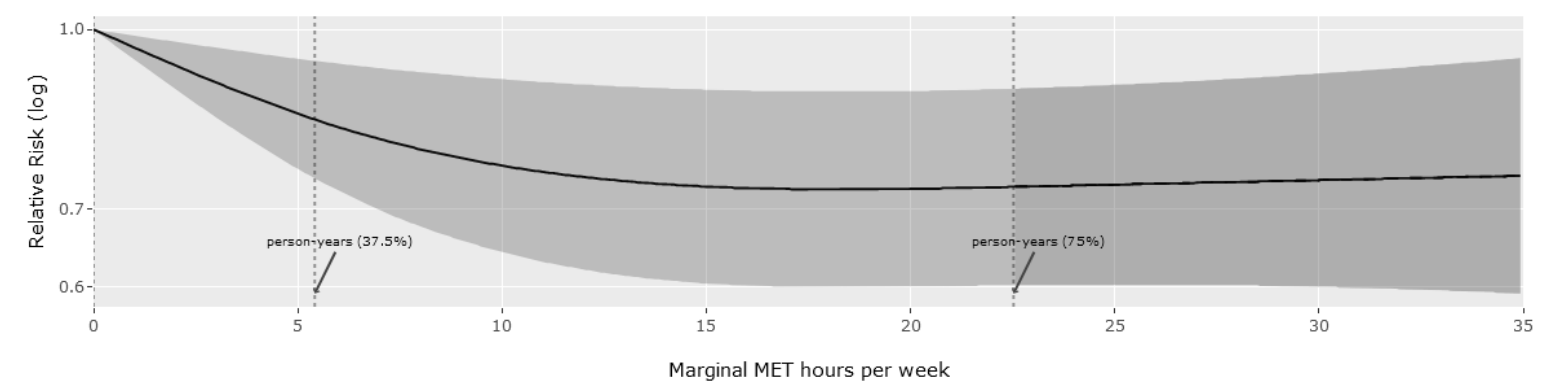

\section{Lung cancer}

Number of entries: 16 \& Person-years: 38,493,208

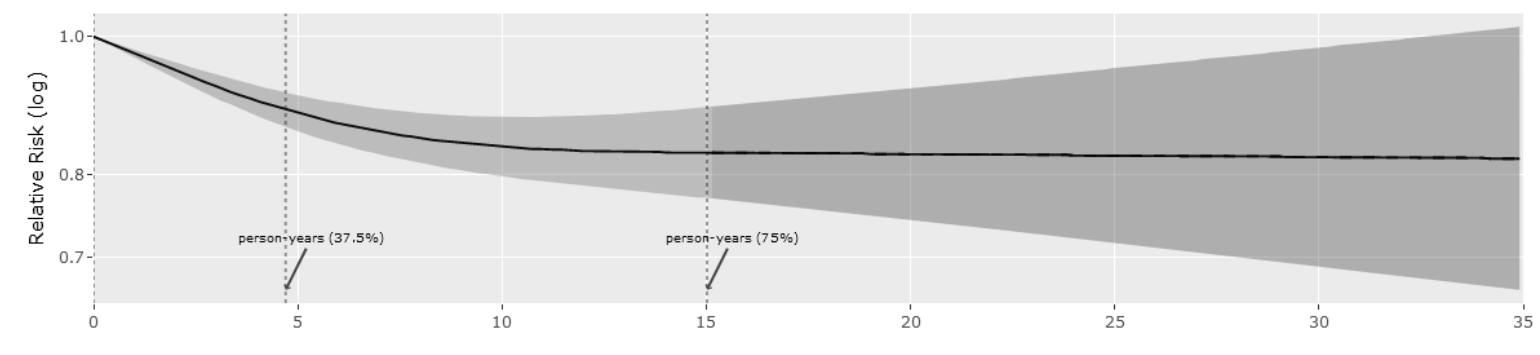

\section{Liver cancer}

Number of entries: 6 \& Person-years: 20,366,608

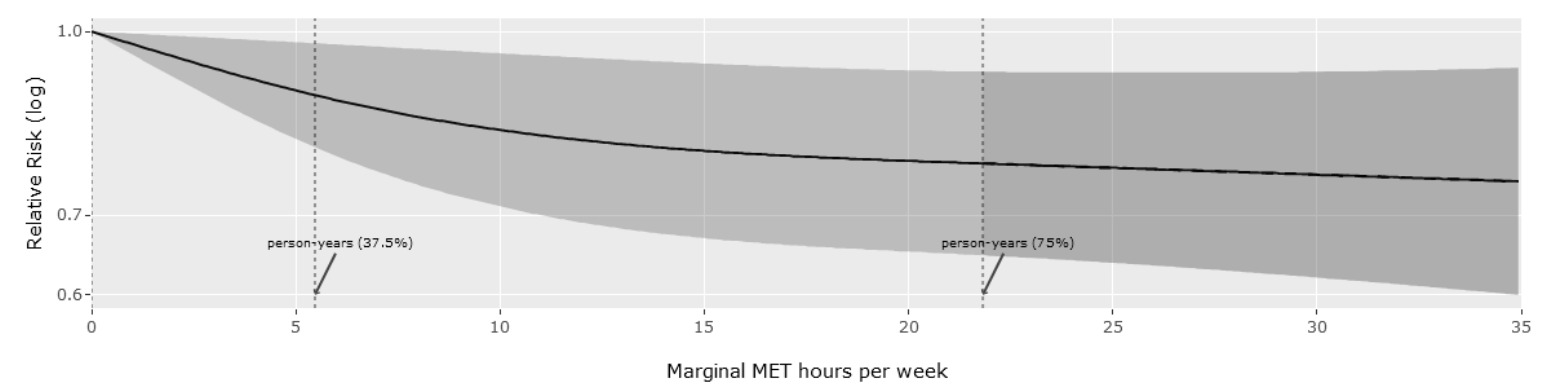

\section{Endometrial cancer}

Number of entries: 13 \& Person-years: 8,999,697

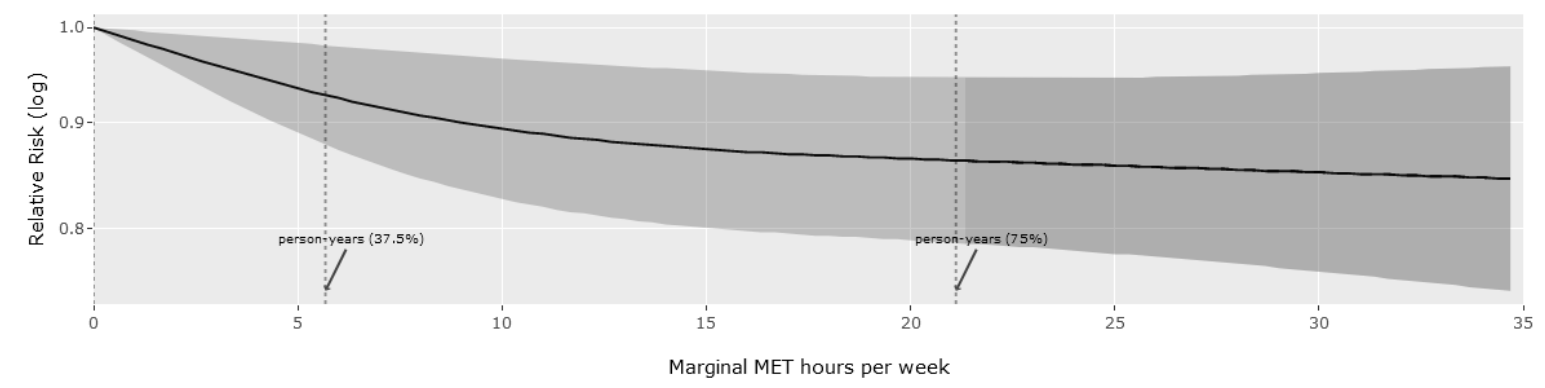


medRxiv preprint doi: https://doi.org/10.1101/2022.03.02.22271753; this version posted March 2, 2022. The copyright holder for this preprint (which was not certified by peer review) is the author/funder, who has granted medRxiv a license to display the preprint in perpetuity.

\section{It is made available under a CC-BY 4.0 International license .}

\section{Colon cancer}

Number of entries: 20 \& Person-years: 28,680,262

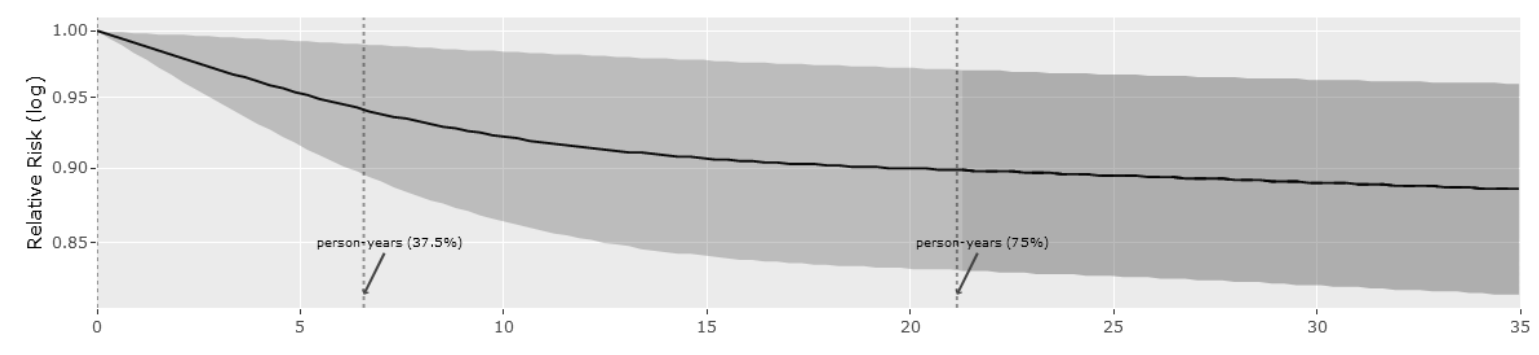

Marginal MET hours per week

\section{Breast cancer}

Number of entries: 29 \& Person-years: 20,316,822

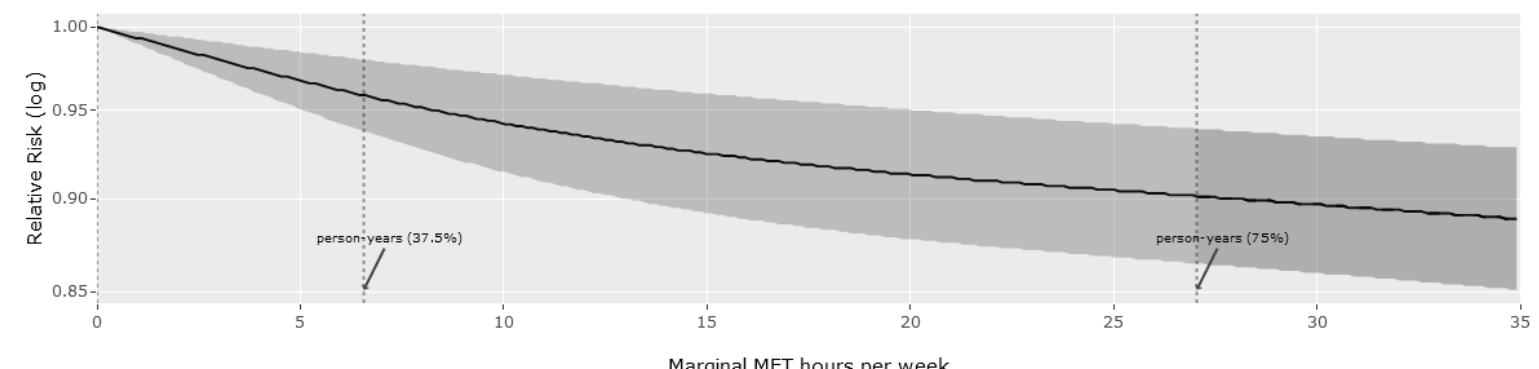

\section{Bladder cancer}

Number of entries: 4 \& Person-years: 7,613,337

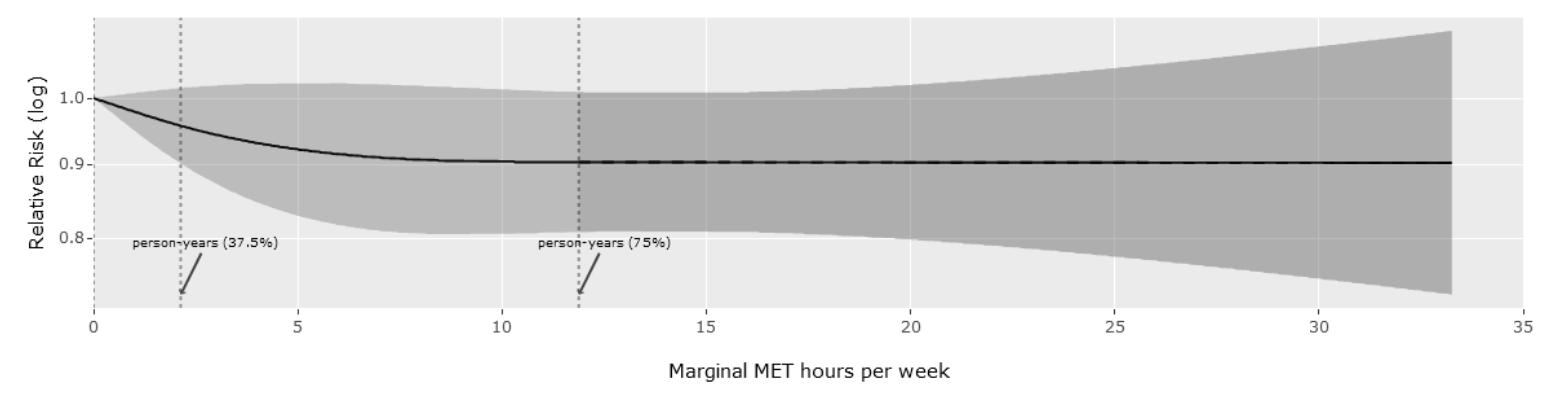

\section{Rectum cancer}

Number of entries: 15 \& Person-years: 23,492,325

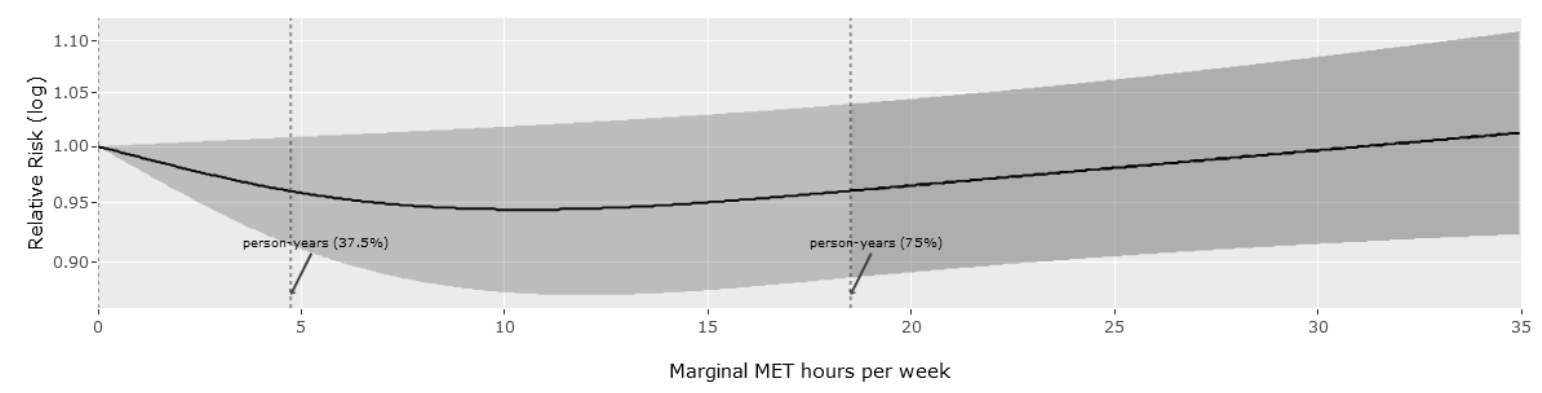


medRxiv preprint doi: https://doi.org/10.1101/2022.03.02.22271753; this version posted March 2, 2022. The copyright holder for this preprint (which was not certified by peer review) is the author/funder, who has granted medRxiv a license to display the preprint in perpetuity.

\section{It is made available under a CC-BY 4.0 International license .}

\section{Esophageal cancer}

Number of entries: 7 \& Person-years: 16,339,443

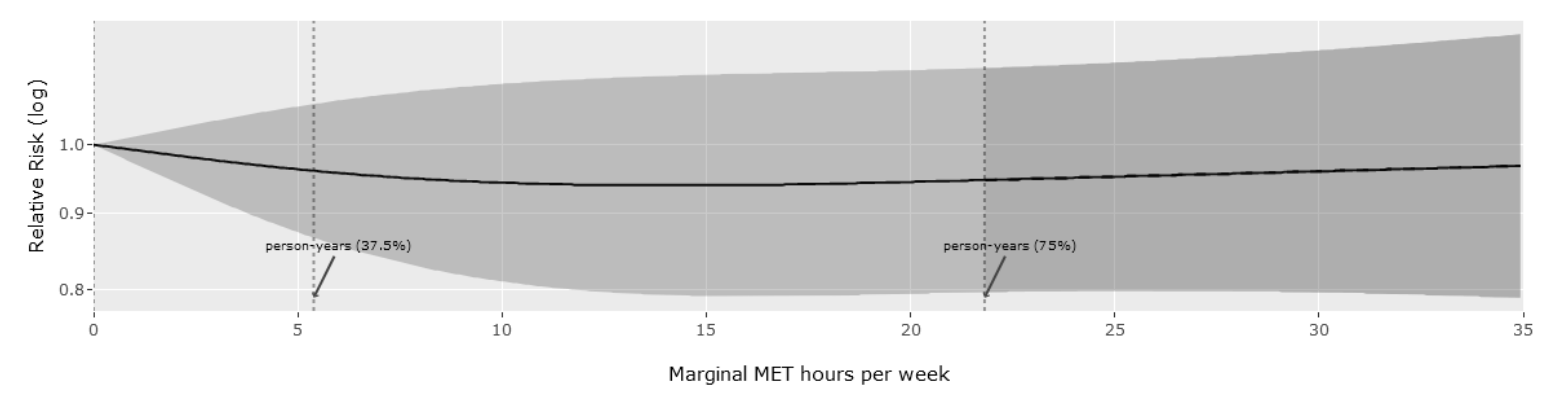

\section{Prostate cancer}

Number of entries: 16 \& Person-years: 11,966,545

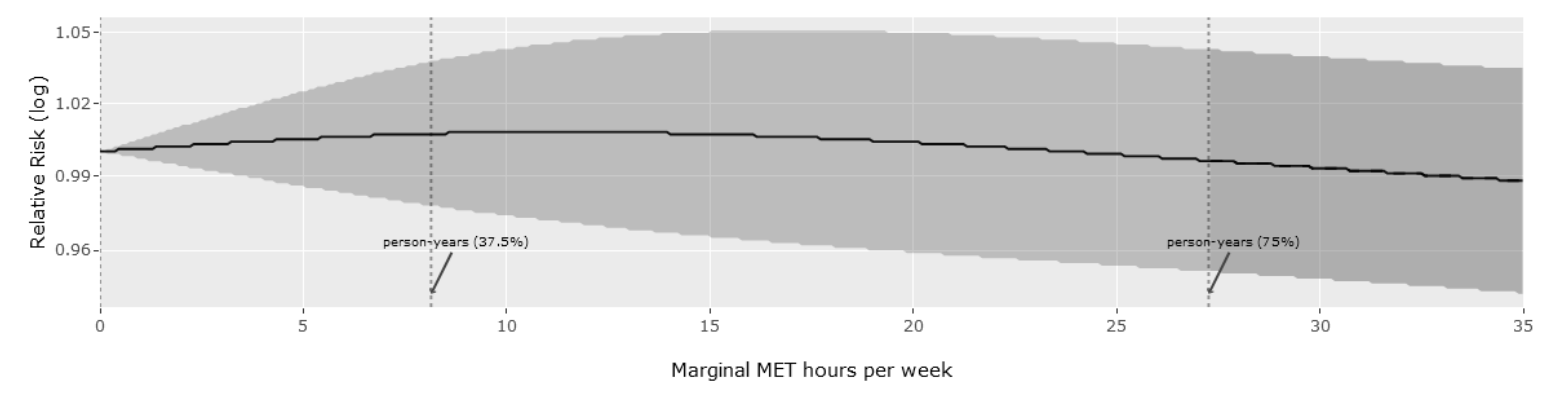

\section{Kidney cancer}

Number of entries: 7 \& Person-years: 12,748,022

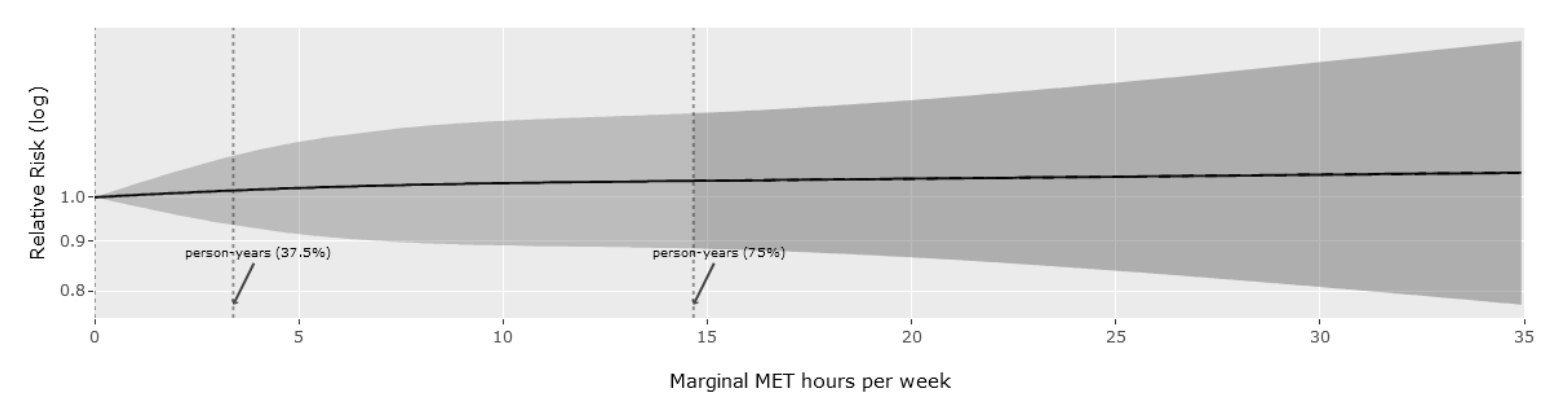

Figure 4. Dose-response association between non-occupational physical activity and incidence of cancers. Vertical dashed lines: cubic spline knots $\left(0^{\text {th }}, 37.5^{\text {th }}\right.$, and $75^{\text {th }}$ percentile of person-years) Dark grey area beyond upper knot: constrained to be linear. 
medRxiv preprint doi: https://doi.org/10.1101/2022.03.02.22271753; this version posted March 2, 2022. The copyright holder for this preprint (which was not certified by peer review) is the author/funder, who has granted medRxiv a license to display the preprint in perpetuity.

It is made available under a CC-BY 4.0 International license .

Table 1. Relative risk of mortality and incidence of cardiovascular diseases and cancers at three physical activity levels, and respective potential impact fractions.

\begin{tabular}{|c|c|c|c|c|c|c|}
\hline \multirow[b]{2}{*}{ Outcomes } & \multicolumn{2}{|c|}{$4.375 \mathrm{mMET}-\mathrm{h} /$ week } & \multicolumn{2}{|c|}{$8.75 \mathrm{mMET}-\mathrm{h} /$ week } & \multicolumn{2}{|c|}{17.5 mMET-h/week } \\
\hline & $\mathrm{RR}(95 \% \mathrm{CI})$ & PIF (95\% CI) & $\operatorname{RR}(95 \% \mathrm{Cl})$ & PIF (95\% Cl) & $\operatorname{RR}(95 \% \mathrm{Cl})$ & PIF (95\% Cl) \\
\hline \multicolumn{7}{|l|}{ Mortality } \\
\hline All-cause mortality & $\begin{array}{c}0.77 \\
(0.73-0.80)\end{array}$ & $\begin{array}{c}10.11 \\
(8.32-11.91)\end{array}$ & $\begin{array}{c}0.69 \\
(0.65-0.73)\end{array}$ & $\begin{array}{c}15.66 \\
(13.16-18.15)\end{array}$ & $\begin{array}{c}0.66 \\
(0.62-0.70)\end{array}$ & $\begin{array}{c}0.66 \\
(0.62-0.70)\end{array}$ \\
\hline Total CVD & $\begin{array}{c}0.81 \\
(0.77-0.85)\end{array}$ & $\begin{array}{c}6.02 \\
(4.42-7.69)\end{array}$ & $\begin{array}{c}0.71 \\
(0.66-0.77)\end{array}$ & $\begin{array}{c}12.25 \\
(9.37-15.17)\end{array}$ & $\begin{array}{c}0.65 \\
(0.60-0.71)\end{array}$ & $\begin{array}{c}0.65 \\
(0.60-0.71)\end{array}$ \\
\hline Total cancer & $\begin{array}{c}0.90 \\
(0.88-0.93)\end{array}$ & $\begin{array}{c}3.68 \\
(2.54-4.86)\end{array}$ & $\begin{array}{c}0.85 \\
(0.81-0.89)\end{array}$ & $\begin{array}{c}7.05 \\
(5.1-9.00)\end{array}$ & $\begin{array}{c}0.82 \\
(0.78-0.86)\end{array}$ & $\begin{array}{c}0.82 \\
(0.78-0.86)\end{array}$ \\
\hline \multicolumn{7}{|l|}{ CVD incidence } \\
\hline Total CVD & $\begin{array}{c}0.83 \\
(0.79-0.87)\end{array}$ & $\begin{array}{c}5.29 \\
(3.93-6.70)\end{array}$ & $\begin{array}{c}0.73 \\
(0.69-0.79)\end{array}$ & $\begin{array}{c}10.86 \\
(8.43-13.31)\end{array}$ & $\begin{array}{c}0.67 \\
(0.63-0.72)\end{array}$ & $\begin{array}{c}0.67 \\
(0.63-0.72)\end{array}$ \\
\hline Coronary heart disease & $\begin{array}{c}0.86 \\
(0.83-0.90)\end{array}$ & $\begin{array}{c}5.51 \\
(3.95-7.11)\end{array}$ & $\begin{array}{c}0.79 \\
(0.74-0.84)\end{array}$ & $\begin{array}{c}10.28 \\
(7.61-12.96)\end{array}$ & $\begin{array}{c}0.74 \\
(0.69-0.80)\end{array}$ & $\begin{array}{c}0.74 \\
(0.69-0.80)\end{array}$ \\
\hline Stroke & $\begin{array}{c}0.86 \\
(0.83-0.90)\end{array}$ & $\begin{array}{c}5.53 \\
(3.96-7.15)\end{array}$ & $\begin{array}{c}0.80 \\
(0.75-0.85)\end{array}$ & $\begin{array}{c}9.77 \\
(7.31-12.24)\end{array}$ & $\begin{array}{c}0.77 \\
(0.72-0.82)\end{array}$ & $\begin{array}{c}0.77 \\
(0.72-0.82)\end{array}$ \\
\hline Heart failure & $\begin{array}{c}0.90 \\
(0.85-0.96)\end{array}$ & $\begin{array}{c}2.23 \\
(0.80-3.89)\end{array}$ & $\begin{array}{c}0.80 \\
4(0.75-0.93)\end{array}$ & $\begin{array}{c}4.63 \\
(1.90-7.66)\end{array}$ & $\begin{array}{c}0.77 \\
(0.68-0.87)\end{array}$ & $\begin{array}{c}0.77 \\
(0.68-0.87)\end{array}$ \\
\hline \multicolumn{7}{|l|}{ Cancer incidence } \\
\hline Total cancer & $\begin{array}{c}0.93 \\
(0.91-0.95)\end{array}$ & $\begin{array}{c}2.53 \\
(1.66-3.42)\end{array}$ & $\begin{array}{c}0.88 \\
(0.85-0.92)\end{array}$ & $\begin{array}{c}5.22 \\
(3.55-6.90)\end{array}$ & $\begin{array}{c}0.85 \\
(0.81-0.89)\end{array}$ & $\begin{array}{c}0.85 \\
(0.81-0.89)\end{array}$ \\
\hline Head and neck & $\begin{array}{c}0.74 \\
(0.59-0.94)\end{array}$ & $\begin{array}{c}10.59 \\
(2.10-19.96)\end{array}$ & $\begin{array}{c}0.65 \\
(0.46-0.91)\end{array}$ & $\begin{array}{c}17.46 \\
(3.68-30.98)\end{array}$ & $\begin{array}{c}0.63 \\
(0.42-0.94)\end{array}$ & $\begin{array}{c}0.63 \\
(0.42-0.94)\end{array}$ \\
\hline Myeloid leukaemia & $\begin{array}{c}0.80 \\
(0.66-0.97)\end{array}$ & $\begin{array}{c}4.93 \\
(0.68-9.70)\end{array}$ & $\begin{array}{c}0.75 \\
(0.60-0.95)\end{array}$ & $\begin{array}{c}7.08 \\
(1.65-12.94)\end{array}$ & $\begin{array}{c}0.75 \\
(0.60-0.94)\end{array}$ & $\begin{array}{c}0.75 \\
(0.60-0.94)\end{array}$ \\
\hline Myeloma & $\begin{array}{c}0.84 \\
(0.74-0.95)\end{array}$ & $\begin{array}{c}3.34 \\
(0.90-6.26)\end{array}$ & $\begin{array}{c}0.75 \\
(0.61-0.92)\end{array}$ & $\begin{array}{c}6.76 \\
(1.90-12.09)\end{array}$ & $\begin{array}{c}0.72 \\
(0.57-0.92)\end{array}$ & $\begin{array}{c}0.72 \\
(0.57-0.92)\end{array}$ \\
\hline Gastric cardia & $\begin{array}{c}0.86 \\
(0.78-0.95)\end{array}$ & $\begin{array}{c}1.95 \\
(0.58-3.68)\end{array}$ & $\begin{array}{c}0.78 \\
(0.66-0.91)\end{array}$ & $\begin{array}{c}4.77 \\
(1.58-8.57)\end{array}$ & $\begin{array}{c}0.73 \\
(0.60-0.88)\end{array}$ & $\begin{array}{c}0.73 \\
(0.60-0.88)\end{array}$ \\
\hline Lung & $\begin{array}{c}0.89 \\
(0.87-0.92)\end{array}$ & $\begin{array}{c}4.39 \\
(3.16-5.63)\end{array}$ & $\begin{array}{c}0.84 \\
(0.81-0.88)\end{array}$ & $\begin{array}{c}7.26 \\
(5.10-9.40)\end{array}$ & $\begin{array}{c}0.83 \\
(0.76-0.91)\end{array}$ & $\begin{array}{c}0.83 \\
(0.76-0.91)\end{array}$ \\
\hline Liver & $\begin{array}{c}0.90 \\
(0.83-0.98)\end{array}$ & $\begin{array}{c}3.49 \\
(0.58-6.71)\end{array}$ & $\begin{array}{c}0.84 \\
(0.73-0.96)\end{array}$ & $\begin{array}{c}6.75 \\
(1.44-12.31)\end{array}$ & $\begin{array}{c}0.78 \\
(0.66-0.93)\end{array}$ & $\begin{array}{c}0.78 \\
(0.66-0.93)\end{array}$ \\
\hline Endometrial & $\begin{array}{c}0.94 \\
(0.90-0.99)\end{array}$ & $\begin{array}{c}1.10 \\
(0.26-2.02)\end{array}$ & $\begin{array}{c}0.90 \\
(0.84-0.97)\end{array}$ & $\begin{array}{c}2.62 \\
(0.76-4.60)\end{array}$ & $\begin{array}{c}0.87 \\
(0.80-0.95)\end{array}$ & $\begin{array}{c}0.87 \\
(0.80-0.95)\end{array}$ \\
\hline Colon & $\begin{array}{c}0.96 \\
(0.93-0.99)\end{array}$ & $\begin{array}{c}0.70 \\
(0.11-1.33)\end{array}$ & $\begin{array}{c}0.93 \\
(0.87-0.99)\end{array}$ & $\begin{array}{c}1.69 \\
(0.33-3.12)\end{array}$ & $\begin{array}{c}0.90 \\
(0.84-0.97)\end{array}$ & $\begin{array}{c}0.90 \\
(0.84-0.97)\end{array}$ \\
\hline Breast & $\begin{array}{c}0.97 \\
(0.96-0.99)\end{array}$ & $\begin{array}{c}0.69 \\
(0.32-1.07)\end{array}$ & $\begin{array}{c}0.95 \\
(0.92-0.97)\end{array}$ & $\begin{array}{c}1.62 \\
(0.79-2.46)\end{array}$ & $\begin{array}{c}0.92 \\
(0.88-0.96)\end{array}$ & $\begin{array}{c}0.92 \\
(0.88-0.96)\end{array}$ \\
\hline Bladder & $\begin{array}{c}0.93 \\
(0.84-1.02)\end{array}$ & $\begin{array}{c}1.91 \\
(-0.54-4.52)\end{array}$ & $\begin{array}{c}0.90 \\
(0.80-1.02)\end{array}$ & $\begin{array}{c}2.98 \\
(-0.24-6.33)\end{array}$ & $\begin{array}{c}0.90 \\
(0.81-1.01)\end{array}$ & $\begin{array}{c}0.90 \\
(0.81-1.01)\end{array}$ \\
\hline Rectum & $\begin{array}{c}0.96 \\
(0.92-1.01)\end{array}$ & $\begin{array}{c}0.77 \\
(-0.15-1.75)\end{array}$ & $\begin{array}{c}0.95 \\
(0.88-1.02)\end{array}$ & $\begin{array}{c}1.43 \\
(-0.45-3.36)\end{array}$ & $\begin{array}{c}0.96 \\
(0.88-1.04)\end{array}$ & $\begin{array}{c}0.96 \\
(0.88-1.04)\end{array}$ \\
\hline Esophageal & $\begin{array}{c}0.97 \\
(0.89-1.05)\end{array}$ & $\begin{array}{c}0.68 \\
(-0.95-2.68)\end{array}$ & $\begin{array}{c}0.95 \\
(0.82-1.09)\end{array}$ & $\begin{array}{c}1.38 \\
(-2.06-5.32)\end{array}$ & $\begin{array}{c}0.94 \\
(0.79-1.12)\end{array}$ & $\begin{array}{c}0.94 \\
(0.79-1.12)\end{array}$ \\
\hline Prostate & $\begin{array}{c}1.00 \\
(0.99-1.02)\end{array}$ & $\begin{array}{c}-0.10 \\
(-0.48-0.29)\end{array}$ & $\begin{array}{c}1.01 \\
(0.98-1.04)\end{array}$ & $\begin{array}{c}-0.21 \\
(-1.10-0.71)\end{array}$ & $\begin{array}{c}1.01 \\
(0.96-1.05)\end{array}$ & $\begin{array}{c}1.01 \\
(0.96-1.05)\end{array}$ \\
\hline Kidney & $\begin{array}{c}1.02 \\
(0.92-1.13)\end{array}$ & $\begin{array}{c}-0.65 \\
(-3.69-2.81)\end{array}$ & $\begin{array}{c}1.03 \\
(0.89-1.19)\end{array}$ & $\begin{array}{c}-1.23 \\
(-6.39-4.34)\end{array}$ & $\begin{array}{c}1.04 \\
(0.88-1.24)\end{array}$ & $\begin{array}{c}1.04 \\
(0.88-1.24)\end{array}$ \\
\hline
\end{tabular}

$\mathrm{mMET}=$ marginal metabolic equivalent of task; $\mathrm{RR}=$ relative risk; $\mathrm{PIF}=$ potential impact fraction; $95 \% \mathrm{Cl}=95 \%$ confidence interval. $\mathrm{CVD}=$ cardiovascular disease.

\subsection{Potential population impact}

Assuming a causal relationship between non-occupational PA and the examined health outcomes, shifting the distribution of non-occupational PA in the cohorts toward the recommended levels would have averted a substantial fraction of the population disease burden. For example, if all individuals accumulated at least the recommended level of PA (8.75 mMET-h/week), then $15.7 \%(95 \% \mathrm{Cl}: 13.1$ to $18.2 \%), 12.3 \%(95 \% \mathrm{Cl}: 9.4$ to $15.2 \%)$, and $7.1 \%$ (95\% Cl: 5.1 to 9.0\%) of all-cause, CVD-, and cancer-related deaths, respectively, would potentially have been averted. Additionally, 10.9\% (95\% Cl: 8.4 to $13.3 \%)$ and $5.2 \%(95 \% \mathrm{Cl}: 3.6$ to $6.9 \%)$ of all incident cases of CVD and cancer would have been 
medRxiv preprint doi: https://doi.org/10.1101/2022.03.02.22271753; this version posted March 2, 2022. The copyright holder for this preprint (which was not certified by peer review) is the author/funder, who has granted medRxiv a license to display the preprint in perpetuity.

It is made available under a CC-BY 4.0 International license .

prevented. Notably, $10.1 \%(95 \% \mathrm{Cl}: 8.3$ to $11.9 \%)$ of all deaths would have been prevented if all adults achieved at least half the recommended PA level (Table 1).

\subsection{Subgroup analysis}

\subsubsection{Pooled estimates from studies that reported results for all-cause, CVD, and cancer mortality}

The pooled analysis from the 11 studies that reported results for all-cause, CVD, and cancer mortality showed weaker associations for all-cause mortality and stronger associations for CVD and cancer mortality (Supplement, eResults 1).

\subsubsection{Sex-stratified results}

Sex-stratified results were available for all-cause, CVD, and cancer mortality and incidence of total CVD, coronary heart disease, stroke, total cancer, and cancers of the colon and rectum. There was some evidence of stronger associations in women than in men for all-cause and CVD mortality and CVD incidence, but the reverse for cancer mortality and incidence (Supplement, eResults 2).

\subsection{Risk of bias}

Across the five outcomes with the largest number of independent results (all-cause mortality, and total CVD and cancer mortality and incidence), 83 to $93 \%$ of the studies used statistical adjustments to control for other morbid ities, often combined with exclusion of adults with some more serious pre-existing conditions at baseline. Studies that predominantly used statistical adjustments tended to report stronger associations for CVD mortality compared with studies that excluded adults with pre-existing conditions at baseline. Between 54 and $59 \%$ of the studies did not exclude mortality and disease events occurring within the first few years of follow-up, and those that did tended to report weaker associations for all-cause mortality and CVD mortality and incidence. Data imputation was required for 58 to $64 \%$ of the studies, but no evidence of bias was found. The most frequently used procedures for exposure harmonization were measurement unit conversions ( 42 to $49 \%$ of studies) and the assumption of standard values for the intensity and duration of PA reported ( 39 to $50 \%$ ), but no evidence of bias was found. In $75 \%$ of the studies, the original exposure assessment did not include occupational PA and no evidence of bias was observed for studies requiring domain separation (Supplement, eResults 3). 
medRxiv preprint doi: https://doi.org/10.1101/2022.03.02.22271753; this version posted March 2, 2022. The copyright holder for this preprint (which was not certified by peer review) is the author/funder, who has granted medRxiv a license to display the preprint in perpetuity.

It is made available under a CC-BY 4.0 International license.

\subsection{Sensitivity analyses}

In studies that did not report the duration or intensity of PA, assuming (where appropriate) shorter session duration (0.5 instead of 0.75 hour) and lower intensity (1 mMET lower for moderate and vigorous PA) did not materially alter the dose-response associations for most outcomes, especially analyses which included the largest number of independent results (Supplement, eResults 4). When shorter duration and lower intensity were used, associations were stronger for CVD outcomes, particularly at lower PA volumes. Placing the restricted cubic spline knots at the $42.5^{\text {th }}$ and $85^{\text {th }}$ percentiles resulted in less stable estimations at higher PA volumes, with those specific segments of the dose-response curves being based on less data and with a higher risk of exposure misclassification.

Sensitivity analyses using analytical models that did not include adjustment for adiposity showed stronger associations for all-cause and CVD mortality, and the incidence of total CVD, heart failure, and site-specific cancers of the endometrium, kidney, lung, and rectum (Supplement, eResults 4). Notably, the association was significant for rectal cancer.

\section{DISCUSSION}

We present comprehensive dose-response meta-analyses of the associations between non-occupational PA and a wide range of mortality and disease outcomes. Our extensive exposure data harmonization allowed inclusion of a larger evidence base than previous meta-analyses for $17 / 22$ health outcomes investigated, including associations for nine site-specific cancers that have not previously been reported.

We showed inverse non-linear dose-response associations for all-cause mortality and a range of CVD and cancer outcomes. This suggests that the greatest potential benefits can be achieved through small increases in nonoccupational PA from an inactive lifestyle, with incrementally smaller additional benefits up to approximately 17.5 mMET-h/week. Above this level, the evidence base was weaker. Shifting population levels of activity toward achieving the min imum PA recommendations of $8.75 \mathrm{mMET}-\mathrm{h} /$ week (equivalent to $150 \mathrm{~min} /$ week of moderate-to-vigorous PA) would potentially have prevented $16 \%$ of all premature deaths recorded.

Compared with previous studies, we found similar associations for all-cause ${ }^{7,20}$ and cancer mortality, ${ }^{21}$ and stronger associations and narrower confidence intervals for CVD mortality ${ }^{219,220}$ at the recommended levels of PA. For cancers of the bladder, breast, colon, endometrium, esophagus, liver and rectum, our results were largely similar to that of a recent pooled analysis. ${ }^{19}$ However, we found stronger associations for cancers of the gastric cardia, head and neck, myeloid leukemia, and myeloma, whereas the association for kidney cancer was non-significant. Contrasting with Moore et al's ${ }^{11}$ finding of harmful effects of PA on prostate cancer, our results did not show an association. 
medRxiv preprint doi: https://doi.org/10.1101/2022.03.02.22271753; this version posted March 2, 2022. The copyright holder for this preprint (which was not certified by peer review) is the author/funder, who has granted medRxiv a license to display the preprint in perpetuity.

It is made available under a CC-BY 4.0 International license .

Comparisons should be interpreted with caution as most previous studies have focused solely on leisure-time $\mathrm{PA}^{7,11,19,}$ ${ }^{20,220}$ and meta-analyses by Li et $a l^{21}$ and Wahid et $a l^{219}$ included studies that assessed PA in any domain.

Compared with results from the $\mathrm{GBD},{ }^{5}$ which have assessed total PA rather than non-occupational PA, we found stronger associations for heart disease and stroke at the minimum recommended PA level. Associations reported by the GBD at approximately $130 \mathrm{MET}-\mathrm{h} /$ week for total PA were observed in our study at $17.5 \mathrm{mMET}-\mathrm{h} /$ week for nonoccupational PA, a much lower volume even considering that we excluded energy expenditure from the resting metabolic rate and occupational activity. Given the challenges of assessing occupational activity, estimates of total PA from self-report are often implausibly high. ${ }^{221}$ Hence, the importance of PA may have been underestimated by the GBD. This, combined with the uncertainties around the health benefits of occupational PA, ${ }^{8,9}$ means our results may be more relevant from a public health perspective.

It is surprising that the risk reduction for all-cause mortality ( $31 \%$ at min imum recommended PA level) is similar to that for total CVD (29\%) and much larger than for total cancer mortality (15\%). Equally, it is surprising that the association for total CVD incidence is stronger than that for coronary heart disease or stroke. Weaker associations would typically be expected for more composite outcomes (e.g., all-cause mortality and total CVD incidence) than for the outcomes within them for which a significant association has been established. Potential explanations include detection bias for some disease events, misclassification of causes of death (especially for more specific disease outcomes), differential residual confounding, reverse causality by outcome, and different inclusion criteria by disease outcome, such as the inclusion of different disease groups which may have stronger associations with PA. ${ }^{222}$ There may also be study-level confounders, and this is supported by our post-hoc subgroup analysis, which showed that studies reporting all three mortality outcomes found stronger associations for CVD than for all-cause mortality. Taken together, it is probable that the risk estimates for all-cause mortality are more accurate than for specific disease outcomes.

A strength of our study was the use of comprehensive exposure data harmonization methods that enabled the inclusion of a larger evidence base. Another strength is the use of more sophisticated meta-analytic methods that allows the shape of the dose-response association to vary across the exposure range, rather than linear models of transformed exposure or grouping doses within high versus low PA or multiple exposure intervals. We improved the placement of spline knots compared to our previous work ${ }^{4}$ by considering the distribution of person-years instead of non-weighted associations across the PA range, acknowledging the paucity of data at higher volumes of PA.

Our study also has limitations. Many of the included studies relied on self-reported questionnaires without any validation or calibration. In the exposure data harmonization procedures, it was also sometimes necessary to make 
medRxiv preprint doi: https://doi.org/10.1101/2022.03.02.22271753; this version posted March 2, 2022. The copyright holder for this preprint (which was not certified by peer review) is the author/funder, who has granted medRxiv a license to display the preprint in perpetuity.

It is made available under a CC-BY 4.0 International license .

assumptions about parameters of physical activity such as intensity and duration where these were not explicitly reported. Nonetheless, our sensitivity analyses demonstrated the robustness of our results to the assumptions made. Measurement error is likely to lead to an underestimation of the true association between PA and the various outcomes, as demonstrated by the stronger associations seen in studies using device-based measures of PA. ${ }^{223}$ Misclassification of some outcomes may be possible as procedures for the ascerta inment of outcomes may not be consistent across all studies. Residual confounding and reverse causation could remain. To mitigate confounding, the most comprehensively adjusted risk estimates were used. However, the level of covariate adjustment and the degree to which these covariates effectively control for confounding may not be consistent across all studies. We excluded studies with less than three years of follow up to mitigate reverse causation. ${ }^{224}$ Although the bias from reverse causation diminishes with longer periods of follow-up, changes in PA level over time could be possible. ${ }^{225,226}$ Our findings support the PA recommendations of 150-300 minutes/week of moderate PA (or 75-150 minutes/week of vigorous PA, or an equivalent combination of moderate and vigorous activities), ${ }^{23}$ in that this exposure level generally seems to equate to maximum or near to maximal benefits. However, the dose-response associations also demonstrate that appreciable health benefits can be gained from 75 minutes/week or less of moderate activity (i.e., half the recommended minimum level of activity). Thus, our findings support the recent change in messaging to "doing some PA is better than doing none", and suggest that the emphasis on threshold-based recommendations could be further reduced.

It should be noted that our exposure estimates are derived from a variety of self-reported questionnaires that capture mostly moderate-to-vigorous activities. These exposure estimates differ from those derived using devicebased measures, which also record light intensity and intermittent activities that are more difficult to recall. ${ }^{223,227,228}$ Self-report and device-based measures are therefore complimentary but not interchangeable, ${ }^{228}$ an important consideration when formulating public health messages.

Future research should investigate reasons for the apparent inconsistencies in dose-response associations between composite and individual disease endpoints. Although our risk of bias and sensitivity analyses showed robustness to the approaches we took during data handling and dose harmonization, future studies could quantify methodological uncertainties (e.g., inaccuracies in exposure assessment) and propagate them in the etiological analyses to provide more realistic uncertainty ranges for the dose-response associations. The evidence base was weaker for higher volumes of activity and further research is required to ascertain the shape of associations more reliably at the higher end of the PA continuum. 
medRxiv preprint doi: https://doi.org/10.1101/2022.03.02.22271753; this version posted March 2, 2022. The copyright holder for this preprint (which was not certified by peer review) is the author/funder, who has granted medRxiv a license to display the preprint in perpetuity.

It is made available under a CC-BY 4.0 International license .

\section{CONCLUSION}

We found evidence of dose-dependent associations between increasing non-occupational PA and a wide range of mortality, CVD, and cancer outcomes. Results showed stronger associations for all-cause and CVD mortality, and weaker associations for the incidence of cancer including variation by site. Appreciable population health benefits can be gained from 75 minutes/week or less of moderate non-occupational PA activity (i.e., half the recommended minimum level of activity).

\section{ACKNOWLEDGEMENTS}

\section{Authors' contributions}

Conception and design: Garcia, Pearce, Mok, Strain, Woodcock, Brage.

Data acquisition: Garcia, Pearce, Mok, Strain, Ali, Dempsey, Golubic, Kelly, Laird, McNamara, Moore, Sa, Smith, Wijndaele.

Statistical analysis: Garcia, Pearce, Abbas, Crippa, Woodcock, Brage.

Software: Abbas.

Interpretation of data: Garcia, Pearce, Mok, Strain, Ali, Crippa, Dempsey, Golubic, Kelly, Laird, McNamara, Moore, Sa, Smith, Wijndaele, Woodcock, Brage.

Drafting of the manuscript: Garcia, Pearce, Mok, Strain, Sa, Woodcock, Brage.

Critical revision of the manuscript: All authors.

All authors approved the submitted version and agreed to be accountable for all aspects of the work.

\section{Guarantors}

Garcia, Pearce, Abbas, Mok, Strain, Woodcock, and Brage had full access to the data, accept full responsibility for the work, and controlled the decision to publish. The corresponding author (Brage) attests that all listed authors meet authorship criteria and that no others meeting the criteria have been omitted.

\section{Disclosure of potential conflicts of interest}

Garcia, Abbas, and Woodcock were supported by METAHIT, an MRC Methodology Panel project (MR/P02663X/1). Abbas, Pearce, and Woodcock have received funding from the European Research Council (ERC) under the Horizon 2020 Research and Innovation Programme (grant agreement 817754) (this material reflects only the author's views, and the Commission is not liable for any use that may be made of the information contained therein). 
medRxiv preprint doi: https://doi.org/10.1101/2022.03.02.22271753; this version posted March 2, 2022. The copyright holder for this preprint (which was not certified by peer review) is the author/funder, who has granted medRxiv a license to display the preprint in perpetuity.

It is made available under a CC-BY 4.0 International license.

Garcia, Abbas, and Woodcock were supported by the Centre for Diet and Activity Research (CEDAR), a UKCRC PUblic Health Research Centre of Excellence funded by the British Heart Foundation, Cancer Research UK, Economic and Social Research Council, Medical Research Council, the National Institute for Health Research (NIHR) and the Wellcome Trust (MR/K023187/1). Dempsey was supported by a National Health and Medical Research Council of Australia Research Fellowship (No. 1142685). Golubic was supported by a Gates Cambridge Scholarship. Pearce and Brage was supported by the NIHR Biomedical Research Centre Cambridge (IS-BRC-1215-20014). Mok was supported by the National Science Scholarship from Singapore, A*STAR. Sa was supported by the São Paulo Research Foundation (2012/08565-4 and 2013/25624-7), and the National Council for Scientific and Technological Development (200358/2014-6 and 402648/2015-3). Pearce, Strain, Dempsey, Wijndaele, and Brage were supported by UK Medical Research Council (MC_UU_12015/3, MC_UU_00006/4). Funders and sponsors had no role in any stage of the work.

All authors declare no financial relationships with any organizations that might have an interest in the submitted work in the previous three years, and no other relationships or activities that could appear to have influenced the submitted work.

\section{Additional contributions}

We thank the authors of original articles who replied to our request for additional information about their analyses: Prof Alejandro Arrieta, Dr Michael Cook, Prof Ulf Ekelund, Prof Edward Giovannucci, Prof Reza Malekzadeh, Dr Jessica Morris, Dr Neil Murphy, Dr Mahdi Nalini, Dr Nicole Niehoff, Dr Tom Nilsen, Dr Annlia Paganini-Hill, Dr Song-Yi Park, Prof Louise Russell, and Prof Wei Zheng. We also thank the IT team of the MRC Epidemiology Unit (University of Cambridge) for setting up the server to host the online results.

\section{References}

1. World Health Organization. Cardiovascular diseases (CVDs). Accessed 18 Aug 2021, https://www.who.int/newsroom/fact-sheets/detail/cardiovascular-diseases-(cvds)

2. Fitzmaurice C, Allen C, Barber RM, et al. Global, regional, and national cancer incidence, mortality, years of life lost, years lived with disability, and disability-adjusted life-years for 32 cancer groups, 1990 to 2015: A systematic analysis for the Global Burden of Disease Study. JAMA Oncol. 2017;3(4):524-548.

3. Lee IM, Shiroma EJ, Lobelo F, Puska P, Blair SN, Katzmarzyk PT. Effect of physical inactivity on major noncommunicable diseases worldwide: an analysis of burden of disease and life expectancy. Lancet. 2012;380(9838):21929.

4. Smith AD, Crippa A, Woodcock J, Brage S. Physical activity and incident type 2 diabetes mellitus: a systematic review and dose-response meta-analysis of prospective cohort studies. Diabetologia. 2016;59(12):2527-2545.

5. Kyu HH, Bachman VF, Alexander LT, et al. Physical activity and risk of breast cancer, colon cancer, diabetes, ischemic heart disease, and ischemic stroke events: systematic review and dose-response meta-analysis for the Global Burden of Disease Study 2013. BMJ. 2016;354:i3857. 
medRxiv preprint doi: https://doi.org/10.1101/2022.03.02.22271753; this version posted March 2, 2022. The copyright holder for this preprint (which was not certified by peer review) is the author/funder, who has granted medRxiv a license to display the preprint in perpetuity.

It is made available under a CC-BY 4.0 International license .

6. Sá TH, Tainio M, Goodman A, et al. Health impact modelling of different travel patterns on physical activity, air pollution and road injuries for São Paulo, Brazil. Environ Int. 2017;108:22-31.

7. Arem H, Moore SC, Patel A, et al. Leisure time physical activity and mortality: a detailed pooled analysis of the doseresponse relationship. JAMA Intern Med. 2015;175(6):959-967.

8. Holtermann A, Schnohr P, Nordestgaard BG, Marott JL. The physical activity paradox in cardiovascular disease and all-cause mortality: the contemporary Copenhagen General Population Study with 104046 adults. Eur Heart J. 2021;42(15):1499-1511.

9. Pearce M, Strain T, Wijndaele K, Sharp SJ, Mok A, Brage S. Is occupational physical activity associated with mortality in UK Biobank? Int J Behav Nutr Phys Act. 2021;18(1):102.

10. Martinez Gomez D, Coenen P, Celis-Morales C, et al. Lifetime high occupational physical activity and total and cause-specific mortality among 320000 adults in the NIH-AARP study: a cohort study. Occup Environ Med. 2021:oemed-2021-107393.

11. Moore SC, Lee IM, Weiderpass $\mathrm{E}$, et al. Association of leisure-time physical activity with risk of 26 types of cancer in 1.44 million adults. JAMA Intern Med. 2016;176(6):816-825.

12. 2018 Physical Activity Guidelines Advisory Committee. 2018 Physical Activity Guidelines Advisory Committee scientific report. U.S. Department of Health and Human Services; 2018.

13. Ainsworth BE, Haskell WL, Herrmann SD, et al. 2011 Compendium of Physical Activities: a second update of codes and MET values. Med Sci Sports Exerc. 2011;43(8):1575-1581.

14. Hamling J, Lee $P$, Weitkunat $R$, Ambühl M. Facilitating meta-analyses by deriving relative effect and precision estimates for alternative comparisons from a set of estimates presented by exposure level or disease category. Stat Med. 2008;27(7):954-970.

15. Greenland S, Longnecker MP. Methods for trend estimation from summarized dose-response data, with applications to meta-analysis. Am J Epidemiol. 1992;135(11):1301-1309.

16. Orsini N, Li R, Wolk A, Khudyakov P, Spiegelman D. Meta-analysis for linear and nonlinear dose-response relations: examples, an evaluation of approximations, and software. Am J Epidemiol. 2012;175(1):66-73.

17. Gasparrini A, Armstrong B, Kenward MG. Multivariate meta-analysis for non-linear and other multi-parameter associations. Stat Med. 2012;31(29):3821-3839.

18. Crippa A, Orsini N. Multivariate dose-response meta-analysis: the dosresmeta R package. J Stat Softw. 2016;72(1):1-15.

19. Matthews $\mathrm{CE}$, Moore SC, Arem $\mathrm{H}$, et al. Amount and intensity of leisure-time physical activity and lower cancer risk. J Clin Oncol. 2020;38(7):686-697.

20. Moore SC, Patel AV, Matthews $\mathrm{CE}$, et al. Leisure time physical activity of moderate to vigorous intensity and mortality: a large pooled cohort analysis. PLOS Med. 2012;9(11):e1001335.

21. Li T, Wei S, Shi Y, et al. The dose-response effect of physical activity on cancer mortality: findings from 71 prospective cohort studies. Br J Sports Med. 2016;50(6):339-345.

22. Zapata-Diomedi B, Barendregt JJ, Veerman JL. Population attributable fraction: names, types and issues with incorrect interpretation of relative risks. Br J Sports Med. 2018;52(4):212-213.

23. World Health Organization. WHO guidelines on physical activity and sedentary behaviour. World Health Organization; 2020.

24. Reddigan $\mathrm{Jl}$, Ardern $\mathrm{Cl}$, Riddell MC, Kuk JL. Relation of physical activity to cardiovascular disease mortality and the influence of cardiometabolic risk factors. Am J Cardiol. 2011;108(10):1426-31.

25. Ekelund U, Ward HA, Norat T, et al. Physical activity and all-cause mortality across levels of overall and abdominal adiposity in European men and women: the European Prospective Investigation into Cancer and Nutrition study (EPIC). Am J Clin Nutr. 2015;101(3):613-621.

26. Kabat GC, Matthews CE, Kamensky V, Hollenbeck AR, Rohan TE. Adherence to cancer prevention guidelines and cancer incidence, cancer mortality, and total mortality: a prospective cohort study. Am J Clin Nutr. 2015;101(3):558569.

27. Carlsson S, Andersson T, Lichtenstein P, Michaëlsson K, Ahlbom A. Physical activity and mortality: Is the association explained by genetic selection? Am J Epidemiol. 2007;166(3):255-259. 
medRxiv preprint doi: https://doi.org/10.1101/2022.03.02.22271753; this version posted March 2, 2022. The copyright holder for this preprint (which was not certified by peer review) is the author/funder, who has granted medRxiv a license to display the preprint in perpetuity.

It is made available under a CC-BY 4.0 International license.

28. Hofmann JN, Moore SC, Lim U, et al. Body mass index and physical activity at different ages and risk of multiple myeloma in the NIH-AARP Diet and Health Study. Am J Epidemiol. 2013;177(8):776-786.

29. Lee IM, Paffenbarger Jr RS. Associations of light, moderate, and vigorous intensity physical activity with longevity: the Harvard Alumni Health Study. Am J Epidemiol. 2000;151(3):293-299.

30. Leitzmann MF, Koebnick C, Abnet CC, et al. Prospective study of physical activity and lung cancer by histologic type in current, former, and never smokers. Am J Epidemiol. 2009;169(5):542-553.

31. Matthews CE, Cohen SS, Fowke JH, et al. Physical activity, sedentary behavior, and cause-specific mortality in black and white adults in the Southern Community Cohort Study. Am J Epidemiol. 2014;180(4):394-405.

32. Moore SC, Chow WH, Schatzkin A, et al. Physical activity during adulthood and adolescence in relation to renal cell cancer. Am J Epidemiol. 2008;168(2):149-157.

33. Patel AV, Bernstein L, Deka A, et al. Leisure time spent sitting in relation to total mortality in a prospective cohort of US adults. Am J Epidemiol. 2010;172(4):419-429.

34. Setiawan VW, Stram DO, Nomura AMY, Kolonel LN, Henderson BE. Risk factors for renal cell cancer: the multiethnic cohort. Am J Epidemiol. 2007;166(8):932-940.

35. Stamatakis E, Hamer M, Lawlor DA. Physical activity, mortality, and cardiovascular disease: is domestic physical activity beneficial? Am J Epidemiol. 2009;169(10):1191-1200.

36. Barreto $P$, Cesari $M$, Andrieu $S$, Vellas $B$, Rolland $Y$. Physical activity and incident chronic diseases: a longitudinal observational study in 16 European countries. Am J Prev Med. 2017;52(3):373-378.

37. Hamer M, De Oliveira C, Demakakos P. Non-exercise physical activity and survival: English Longitudinal Study of Ageing. Am J Prev Med. 2014;47(4):452-460.

38. Ueshima K, Ishikawa-Takata K, Yorifuji T, et al. Physical activity and mortality risk in the Japanese elderly. A cohort study. Am J Prev Med. 2010;38(4):410-418.

39. Albanes D, Blair A, Taylor PR. Physical activity and risk of cancer in the NHANES I population. Am J Public Health. 1989;79(6):744-750.

40. Rockhill B, Willett WC, Manson JE, et al. Physical activity and mortality: a prospective study among women. Am J Public Health. 2001;91(4):578-583.

41. Arrieta A, Russell LB. Effects of leisure and non-leisure physical activity on mortality in U.S. adults over two decades. Ann Epidemiol. 2008;18(12):889-895.

42. Inoue $\mathrm{M}$, Iso $\mathrm{H}$, Yamamoto $\mathrm{S}$, et al. Daily total physical activity level and premature death in men and women: results from a large-scale population-based cohort study in Japan (JPHC Study). Ann Epidemiol. 2008;18(7):522-530.

43. Prineas RJ, Folsom AR, Kaye SA. Central adiposity and increased risk of coronary artery disease mortality in older women. Ann Epidemiol. 1993;3(1):35-41.

44. Cho J, Lee I, Park S, et al. Physical activity and all-cause mortality in Korean older adults. Ann Hum Biol. 2018;45(4):337-345.

45. Walter RB, Buckley SA, White E. Regular recreational physical activity and risk of hematologic malignancies: results from the prospective vitamins and lifestyle (vital) study. Ann Oncol. 2013;24(5):1370-1377.

46. Bardia A, Hartmann LC, Vachon CM, et al. Recreational physical activity and risk of postmenopausal breast cancer based on hormone receptor status. Arch Intern Med. 2006;166(22):2478-2483.

47. Rockhill B, Willett WC, Hunter DJ, Manson JE, Hankinson SE, Colditz GA. A prospective study of recreational physical activity and breast cancer risk. Arch Intern Med. 1999;159(19):2290-2296.

48. Schooling CM, Lam TH, Li ZB, et al. Obesity, physical activity, and mortality in a prospective chinese elderly cohort. Arch Intern Med. 2006;166(14):1498-504.

49. Suzuki K. Health conditions and mortality in the Japan Collaborative Cohort Study for Evaluation of Cancer (JACC). Asian Pac J Cancer Prev. 2007;8(Suppl):25-34.

50. Hu G, Jousilahti P, Borodulin K, et al. Occupational, commuting and leisure-time physical activity in relation to coronary heart disease among middle-aged Finnish men and women. Atherosclerosis. 2007;194(2):490-497. 
medRxiv preprint doi: https://doi.org/10.1101/2022.03.02.22271753; this version posted March 2, 2022. The copyright holder for this preprint (which was not certified by peer review) is the author/funder, who has granted medRxiv a license to display the preprint in perpetuity.

It is made available under a CC-BY 4.0 International license .

51. Oyeyemi SO, Braaten T, Licaj I, Lund E, Benjaminsen Borch K. Physical activity patterns and the risk of colorectal cancer in the Norwegian Women and Cancer study: a population-based prospective study. BMC Cancer.

2018;18(1):1216.

52. Jee Y, Kim Y, Jee SH, Ryu M. Exercise and cancer mortality in Korean men and women: a prospective cohort study. BMC Public Health. 2018;18(1):761.

53. Nunez C, Nair-Shalliker V, Egger S, Sitas F, Bauman A. Physical activity, obesity and sedentary behaviour and the risks of colon and rectal cancers in the 45 and up study. BMC Public Health. 2018;18(1)

54. Nalini M, Oranuba E, Poustchi $\mathrm{H}$, et al. Causes of premature death and their associated risk factors in the Golestan Cohort Study, Iran. BMJ Open. 2018;8(7):e021479.

55. Leitzmann MF, Moore SC, Peters TM, et al. Prospective study of physical activity and risk of postmenopausal breast cancer. Breast Cancer Res. 2008;10(5):R92.

56. Ma H, Xu X, Clague J, et al. Recreational physical activity and risk of triple negative breast cancer in the California Teachers Study. Breast Cancer Res. 2016;18:62.

57. Navarro Silvera $S A$, Jain $M$, Howe GR, Miller AB, Rohan TE. Energy balance and breast cancer risk: a prospective cohort study. Breast Cancer Res Treat. 2006;97(1):97-106.

58. Dieli-Conwright $\mathrm{CM}, \mathrm{Ma} \mathrm{H}$, Lacey JV, et al. Long-term and baseline recreational physical activity and risk of endometrial cancer: the California Teachers Study. Br J Cancer. 2013;109(3):761-768.

59. Morris JS, Bradbury KE, Cross AJ, Gunter MJ, Murphy N. Physical activity, sedentary behaviour and colorectal cancer risk in the UK Biobank. Br J Cancer. 2018;118(6):920-929.

60. Orsini N, Bellocco R, Bottai M, et al. A prospective study of lifetime physical activity and prostate cancer incidence and mortality. Br J Cancer. 2009;101(11):1932-1938.

61. Orsini N, Mantzoros CS, Wolk A. Association of physical activity with cancer incidence, mortality, and survival: a population-based study of men. BrJ Cancer. 2008;98(11):1864-1869.

62. Pronk A, Ji BT, Shu XO, et al. Physical activity and breast cancer risk in Chinese women. Br J Cancer. 2011;105(9):1443-1450.

63. Thune I, Lund E. Physical activity and risk of colorectal cancer in men and women. Br J Cancer. 1996;73(9):11341140.

64. Brown WJ, McLaughlin D, Leung J, et al. Physical activity and all-cause mortality in older women and men. $\mathrm{Br} J$ Sports Med. 2012;46(9):664-668.

65. Lee DC, Sui X, Ortega FB, et al. Comparisons of leisure-time physical activity and cardiorespiratory fitness as predictors of all-cause mortality in men and women. Br J Sports Med. 2011;45(6):504-510.

66. Zhao G, Li C, Ford ES, et al. Leisure-time aerobic physical activity, muscle-strengthening activity and mortality risks a mong US adults: the NHANES linked mortality study. Br J Sports Med. 2014;48(3):244-249.

67. Moore SC, Peters TM, Ahn J, et al. Age-specific physical activity and prostate cancer risk among white men and black men. Cancer. 2009;115(21):5060-5070.

68. Tripathi A, Folsom AR, Anderson KE. Risk factors for urinary bladder carcinoma in postmenopausal women: the lowa Women's Health Study. Cancer. 2002;95(11):2316-2323.

69. Bostick RM, Potter JD, Kushi LH, et al. Sugar, meat, and fat intake, and non-dietary risk factors for colon cancer incidence in lowa women (United States). Cancer Causes Control. 1994;5(1):38-52.

70. Colbert LH, Lacey Jr JV, Schairer C, Albert P, Schatzkin A, Albanes D. Physical activity and risk of endometrial cancer in a prospective cohort study (United States). Cancer Causes Control. 2003;14(6):559-567.

71. Conroy MB, Sattelmair JR, Cook NR, Manson JE, Buring JE, Lee IM. Physical activity, adiposity, and risk of endometrial cancer. Cancer Causes Control. 2009;20(7):1107-1115.

72. Giovannucci E, Colditz GA, Stampfer MJ, Willett WC. Physical activity, obesity, and risk of colorectal adenoma in women (United States). Cancer Causes Control. 1996;7(2):253-263.

73. Howard RA, Freedman DM, Park Y, Hollenbeck A, Schatzkin A, Leitzmann MF. Physical activity, sedentary behavior, and the risk of colon and rectal cancer in the NIH-AARP Diet and Health Study. Cancer Causes Control. 2008;19(9):939953. 
medRxiv preprint doi: https://doi.org/10.1101/2022.03.02.22271753; this version posted March 2, 2022. The copyright holder for this preprint (which was not certified by peer review) is the author/funder, who has granted medRxiv a license to display the preprint in perpetuity.

It is made available under a CC-BY 4.0 International license .

74. Howard RA, Leitzmann MF, Linet MS, Freedman DM. Physical activity and breast cancer risk among pre- and postmenopausal women in the U.S. Radiologic Technologists cohort. Cancer Causes Control. 2009;20(3):323-333.

75. Huerta JM, Navarro C, Chirlaque MD, et al. Prospective study of physical activity and risk of primary adenocarcinomas of the oesophagus and stomach in the EPIC (European Prospective Investigation into Cancer and Nutrition) cohort. Cancer Causes Control. 2010;21(5):657-669.

76. Lee IM, Manson JE, Ajani U, Paffenbarger Jr RS, Hennekens CH, Buring JE. Physical activity and risk of colon cancer: the Physicians' Health Study (United States). Cancer Causes Control. 1997;8(4):568-574.

77. Lee IM, Rexrode KM, Cook NR, Hennekens CH, Burin JE. Physical activity and breast cancer risk: the Women's Health Study (United States). Cancer Causes Control. 2001;12(2):137-45.

78. Leitzmann MF, Koebnick C, Freedman ND, et al. Physical activity and head and neck cancer risk. Cancer Causes Control. 2008;19(10):1391-1399.

79. Park SY, Haiman CA, Cheng I, et al. Racial/ethnic differences in lifestyle-related factors and prostate cancer risk: the Multiethnic Cohort Study. Cancer Causes Control. 2015;26(10):1507-1515.

80. Patel AV, Carter BD, Stevens VL, Gaudet MM, Campbell PT, Gapstur SM. The relationship between physical activity, obesity, and lung cancer risk by smoking status in a large prospective cohort of US adults. Cancer Causes Control. 2017;28(12):1357-1368.

81. Thune I, Lund E. Physical activity and the risk of prostate and testicular cancer: a cohort study of 53,000 Norwegian men. Cancer Causes Control. 1994;5(6):549-556.

82. Barberio AM, Friedenreich CM, Lynch BM, Campbell KL, Arora P, Brenner DR. Physical activity and cancer incidence in Alberta's Tomorrow project: results from a prospective cohort of 26,538 participants. Cancer Epidemiol Biomarkers Prev. 2018;27(8):945-954.

83. Birmann BM, Giovannucci E, Rosner B, Anderson KC, Colditz GA. Body mass index, physical activity, and risk of multiple myeloma. Cancer Epidemiol Biomarkers Prev. 2007;16(7):1474-1478.

84. Chang SC, Ziegler RG, Dunn B, et al. Association of energy intake and energy balance with postmenopausal breast cancer in the prostate, lung, colorectal, and ovarian cancer screening trial. Cancer Epidemiol Biomarkers Prev. 2006;15(2):334-341.

85. Chao A, Connell CJ, Jacobs EJ, et al. Amount, type, and timing of recreational physical activity in relation to colon and rectal cancer in older adults: the Cancer Prevention Study II Nutrition Cohort. Cancer Epidemiol Biomarkers Prev. 2004;13(12):2187-2195.

86. Friberg E, Mantzoros CS, Wolk A. Physical activity and risk of endometrial cancer: a population-based prospective cohort study. Cancer Epidemiol Biomarkers Prev. 2006;15(11):2136-2140.

87. Hildebrand IS, Gapstur SM, Campbell PT, Gaudet MM, Patel AV. Recreational physical activity and leisure-time sitting in relation to postmenopausal breast cancer risk. Cancer Epidemiol Biomarkers Prev. 2013;22(10):1906-1912.

88. Kabat GC, Wu JW, Moore SC, et al. Lifestyle and dietary factors in relation to risk of chronic myeloid leukemia in the NIH-AARP diet and health study. Cancer Epidemiol Biomarkers Prev. 2013;22(5):848-854.

89. Koebnick C, Michaud D, Moore SC, et al. Body mass index, physical activity, and bladder cancer in a large prospective study. Cancer Epidemiol Biomarkers Prev. 2008;17(5):1214-1221.

90. Mai PL, Sullivan-Halley J, Ursin G, et al. Physical activity and colon cancer risk among women in the California Teachers Study. Cancer Epidemiol Biomarkers Prev. 2007;16(3):517-525.

91. Margolis KL, Mucci L, Braaten T, et al. Physical activity in different periods of life and the risk of breast cancer: the Norwegian-Swedish Women's Lifestyle and Health cohort study. Cancer Epidemiol Biomarkers Prev. 2005;14(1):27-32.

92. Niehoff NM, Nichols HB, Zhao S, White AJ, Sandler DP. Adult physical activity and breast cancer risk in women with a family history of breast cancer. Cancer Epidemiol Biomarkers Prev. 2019;28(1):51-58.

93. Nilsen TI, Romundstad PR, Petersen H, Gunnell D, Vatten LJ. Recreational physical activity and cancer risk in subsites of the colon (the Nord-Trondelag Health Study). Cancer Epidemiol Biomarkers Prev. 2008;17(1):183-8.

94. Patel AV, Rodriguez C, Jacobs EJ, Solomon L, Thun MJ, Calle EE. Recreational physical activity and risk of prostate cancer in a large cohort of U.S. men. Cancer Epidemiol Biomarkers Prev. 2005;14(1):275-279.

95. Peters TM, Schatzkin A, Gierach GL, et al. Physical activity and postmenopausal breast cancer risk in the NIH-AARP diet and health study. Cancer Epidemiol Biomarkers Prev. 2009;18(1):289-296. 
medRxiv preprint doi: https://doi.org/10.1101/2022.03.02.22271753; this version posted March 2, 2022. The copyright holder for this preprint (which was not certified by peer review) is the author/funder, who has granted medRxiv a license to display the preprint in perpetuity.

It is made available under a CC-BY 4.0 International license .

96. Rosenberg L, Palmer JR, Bethea TN, Ban Y, Kipping-Ruane K, Adams-Campbell LL. A prospective study of physical activity and breast cancer incidence in African-American women. Cancer Epidemiol Biomarkers Prev. 2014;23(11):2522-2531.

97. Sinner P, Folsom AR, Harnack L, Eberly LE, Schmitz KH. The association of physical activity with lung cancer incidence in a cohort of older women: the lowa Women's Health Study. Cancer Epidemiol Biomarkers Prev. 2006;15(12):2359-2363.

98. Sjödahl K, Jia C, Vatten L, Nilsen T, Hveem K, Lagergren J. Body mass and physical activity and risk of gastric cancer in a population-based cohort study in Norway. Cancer Epidemiol Biomarkers Prev. 2008;17(1):135-140.

99. Tehard B, Friedenreich CM, Oppert JM, Clavel-Chapelon F. Effect of physical activity on women at increased risk of breast cancer: results from the E3N cohort study. Cancer Epidemiol Biomarkers Prev. 2006;15(1):57-64.

100. Arem H, Loftfield E, Saint-Maurice PF, Freedman ND, Matthews CE. Physical activity across the lifespan and liver cancer incidence in the NIH-AARP Diet and Health Study cohort. Cancer Med. 2018;7(4):1450-1457.

101. Morikawa T, Kuchiba A, Lochhead P, et al. Prospective analysis of body mass index, physical activity, and colorectal cancer risk associated with b-catenin (ctnnb1) status. Cancer Res. 2013;73(5):1600-1610.

102. Paganini-Hill A. Lifestyle practices and cardiovascular disease mortality in the elderly: the Leisure World Cohort Study. Cardiol Res Pract. 2011:983764.

103. Armstrong ME, Green J, Reeves GK, Beral V, Cairns BJ. Frequent physical activity may not reduce vascular disease risk as much as moderate activity: large prospective study of women in the United Kingdom. Circulation.

2015;131(8):721-9.

104. Chiuve SE, Rexrode KM, Spiegelman D, Logroscino G, Manson JE, Rimm EB. Primary prevention of stroke by healthy lifestyle. Circulation. 2008;118(9):947-54.

105. Chomistek AK, Henschel B, Eliassen AH, Mukamal KJ, Rimm EB. Frequency, type, and volume of leisure-time physical activity and risk of coronary heart disease in young women. Circulation. 2016;134(4):290-299.

106. Fraser GE, Strahan TM, Sabate J, Beeson WL, Kissinger D. Effects of traditional coronary risk-factors on rates of incident coronary events in a low-risk population - the Adventist Health Study. Circulation. 1992;86(2):406-413.

107. Hu G, Jousilahti P, Antikainen R, Katzmarzyk PT, Tuomilehto J. Joint effects of physical activity, body mass index, waist circumference, and waist-to-hip ratio on the risk of heart failure. Circulation. 2010;121(2):237-244.

108. Kenchaiah S, Sesso HD, Gaziano JM. Body mass index and vigorous physical activity and the risk of heart failure among men. Circulation. 2009;119(1):44-52.

109. Sesso HD, Paffenbarger Jr RS, Lee IM. Physical activity and coronary heart disease in men: the Harvard Alumni Health Study. Circulation. 2000;102(9):975-980.

110. Andersen K, Mariosa D, Adami HO, et al. Dose-response relationship of total and leisure time physical activity to risk of heart failure a prospective cohort study. Circ Heart Fail. 2014;7(5):701-708.

111. Rahman I, Bellavia A, Wolk A. Relationship between physical activity and heart failure risk in women. Circ Heart Fail. $2014 ; 7(6): 877-881$.

112. Young DR, Reynolds K, Sidell M, et al. Effects of physical activity and sedentary time on the risk of heart failure. Circ Heart Fail. 2014;7(1):21-27.

113. Borch KB, Braaten T, Lund E, Weiderpass E. Physical activity and mortality among Norwegian women - the Norwegian Women and Cancer Study. Clin Epidemiol. 2011;3:229-35.

114. Murphy N, Ward HA, Jenab M, et al. Heterogeneity of colorectal cancer risk factors by anatomical subsite in 10 European countries: a multinational cohort study. Clin Gastroenterol Hepatol. 2018;17(7):1323-1331.e6.

115. Villeneuve PJ, Morrison HI, Craig CL, Schaubel DE. Physical activity, physical fitness, and risk of dying. Epidemiology. 1998;9(6):626-631.

116. Hu G, Tuomilehto J, Silventoinen K, Barengo N, Jousilahti P. Joint effects of physical activity, body mass index, waist circumference and waist-to-hip ratio with the risk of cardiovascular disease among middle-aged Finn ish men and women. Eur Heart J. 2004;25(24):2212-2219.

117. Pedersen JO, Heitmann BL, Schnohr P, Gronbaek M. The combined influence of leisure-time physical activity and weekly alcohol intake on fatal ischaemic heart disease and all-cause mortality. Eur Heart J. 2008;29(2):204-12. 
medRxiv preprint doi: https://doi.org/10.1101/2022.03.02.22271753; this version posted March 2, 2022. The copyright holder for this preprint (which was not certified by peer review) is the author/funder, who has granted medRxiv a license to display the preprint in perpetuity.

It is made available under a CC-BY 4.0 International license .

118. Larsson SC, Rutegard J, Bergkvist L, Wolk A. Physical activity, obesity, and risk of colon and rectal cancer in a cohort of Swedish men. Eur J Cancer. 2006;42(15):2590-7.

119. Eaglehouse YL, Koh WP, Wang R, Aizhen J, Yuan JM, Butler LM. Physical activity, sedentary time, and risk of colorectal cancer: the Singapore Chinese Health Study. Eur J Cancer Prev. 2017;26(6):469-475.

120. Wisloff U, Nilsen TI, Droyvold WB, Morkved S, SlordahI SA, Vatten L. A single weekly bout of exercise may reduce cardiovascular mortality: how little pain for cardiac gain? 'The HUNT study, Norway'. Eur J Cardiovasc Prev Rehabil. 2006;13(5):798-804.

121. Bellocco R, Jia C, Ye W, Lagerros YT. Effects of physical activity, body mass index, waist-to-hip ratio and waist circumference on total mortality risk in the Swedish National March Cohort. Eur J Epidemiol. 2010;25(11):777-788.

122. Bellocco R, Marrone $G$, Ye W, et al. A prospective cohort study of the combined effects of physical activity and anthropometric measures on the risk of post-menopausal breast cancer. Eur J Epidemiol. 2016;31(4):395-404.

123. Borch KB, Weiderpass E, Braaten T, Hansen MS, Licaj I. Risk of lung cancer and physical activity by smoking status and body mass index, the Norwegian Women and Cancer Study. Eur J Epidemiol. 2019;34(5):489-498.

124. Hamer M, O'Donovan G, Stamatakis E. Association between physical activity and sub-types of cardiovascular disease death causes in a general population cohort. Eur J Epidemiol. 2019;34(5):483-487.

125. Luoto R, Latikka P, Pukkala E, Hakulinen T, Vihko V. The effect of physical activity on breast cancer risk: a cohort study of 30,548 women. Eur J Epidemiol. 2000;16(10):973-980.

126. Allesoe K, Holtermann A, Aadahl M, Thomsen JF, Hundrup YA, Sogaard K. High occupational physical activity and risk of ischaemic heart disease in women: the interplay with physical activity during leisure time. Eur J Prev Cardiol. 2015;22(12):1601-8.

127. Alvarez-Alvarez I, de Rojas JP, Fernandez-Montero A, et al. Strong inverse associations of Mediterranean diet, physical activity and their combination with cardiovascular disease: the Seguimiento Universidad de Navarra (SUN) cohort. Eur J Prev Cardiol. 2018;25(11):1186-1197.

128. Hashibe M, Hunt J, Wei M, Buys S, Gren L, Lee YCA. Tobacco, alcohol, body mass index, physical activity, and the risk of head and neck cancer in the Prostate, Lung, Colorectal, and Ovarian (PLCO) cohort. Head Neck. 2013;35(7):914922.

129. Arem H, Moore SC, Park Y, et al. Physical activity and cancer-specific mortality in the NIH-AARP Diet and Health Study cohort. Int J Cancer. 2014;135(2):423-431.

130. Bergström A, Terry P, Lindblad P, et al. Physical activity and risk of renal cell cancer. Int J Cancer. 2001;92(1):155157.

131. Borch KB, Weiderpass E, Braaten T, Jareid M, Gavrilyuk OA, Licaj I. Physical activity and risk of endometrial cancer in the Norwegian Women and Cancer (NOWAC) study. Int J Cancer. 2017;140(8):1809-1818.

132. Calton BA, Lacey Jr JV, Schatzkin A, et al. Physical activity and the risk of colon cancer among women: a prospective cohort study (United States). Int J Cancer. 2006;119(2):385-391.

133. Du M, Kraft P, Eliassen AH, Giovannucci E, Hankinson SE, De Vivo I. Physical activity and risk of endometrial adenocarcinoma in the Nurses' Health Study. Int J Cancer. 2014;134(11):2707-2716.

134. Friedenreich C, Cust A, Lahmann PH, et al. Physical activity and risk of endometrial cancer: the European Prospective Investigation into Cancer and Nutrition. Int J Cancer. 2007;121(2):347-355.

135. Furberg AS, Thune I. Metabolic abnormalities (hypertension, hyperglycemia and overweight), lifestyle (high energy intake and physical inactivity) and endometrial cancer risk in a Norwegian cohort. Int J Cancer.

2003;104(6):669-676.

136. Gierach GL, Chang SC, Brinton LA, et al. Physical activity, sedentary behavior, and endometrial cancer risk in the NIH-AARP Diet and Health Study. Int J Cancer. 2009;124(9):2139-2147.

137. Giovannucci E, Liu Y, Platz EA, Stampfer MJ, Willett WC. Risk factors for prostate cancer incidence and progression in the health professionals follow-up study. Int J Cancer. 2007;121(7):1571-1578.

138. Holick CN, Giovannucci EL, Stampfer MJ, Michaud DS. Prospective study of body mass index, height, physical activity and incidence of bladder cancer in US men and women. Int J Cancer. 2007;120(1):140-146.

139. Johnsen NF, Tjønneland A, Thomsen BLR, et al. Physical activity and risk of prostate cancer in the European Prospective Investigation into Cancer and Nutrition (EPIC) cohort. Int J Cancer. 2009;125(4):902-908. 
medRxiv preprint doi: https://doi.org/10.1101/2022.03.02.22271753; this version posted March 2, 2022. The copyright holder for this preprint (which was not certified by peer review) is the author/funder, who has granted medRxiv a license to display the preprint in perpetuity.

It is made available under a CC-BY 4.0 International license .

140. Nicodemus KK, Sweeney C, Folsom AR. Evaluation of dietary, medical and lifestyle risk factors for incident kidney cancer in postmenopausal women. Int J Cancer. 2004;108(1):115-121.

141. Nilsen TI, Romundstad PR, Vatten L. Recreational physical activity and risk of prostate cancer: a prospective population-based study in Norway (the HUNT study). Int I Cancer. 2006;119(12):2943-7.

142. Patel AV, Feigelson HS, Talbot JT, et al. The role of body weight in the relationship between physical activity and endometrial cancer: results from a large cohort of US women. Int J Cancer. 2008;123(8):1877-1882.

143. Steindorf K, Friedenreich C, Linseisen J, et al. Physical activity and lung cancer risk in the European Prospective Investigation into Cancer and Nutrition cohort. Int J Cancer. 2006;119(10):2389-2397.

144. Steindorf K, Ritte R, Eomois PP, et al. Physical activity and risk of breast cancer overall and by hormone receptor status: the European Prospective Investigation into Cancer and Nutrition. Int J Cancer. 2013;132(7):1667-78.

145. Thune I, Lund $E$. The influence of physical activity on lung-cancer risk. A prospective study of 81,516 men and women. Int J Cancer. 1997;70(1):57-62.

146. Wei EK, Giovannucci E, Wu K, et al. Comparison of risk factors for colon and rectal cancer. Int I Cancer. 2004;108(3):433-442.

147. Khaw $\mathrm{KT}$, Jakes $\mathrm{R}$, Bingham $\mathrm{S}$, et al. Work and leisure time physical activity assessed using a simple, pragmatic, validated questionnaire and incident cardiovascular disease and all-cause mortality in men and women: the European Prospective Investigation into Cancer in Norfolk prospective population study. Int J Epidemiol. 2006;35(4):1034-1043.

148. Liu S, Lee IM, Linson P, Ajani U, Buring JE, Hennekens CH. A prospective study of physical activity and risk of prostate cancer in US physicians. Int J Epidemiol. 2000;29(1):29-35.

149. Hu G, Tuomilehto J, Silventoinen K, Barengo NC, Peltonen M, Jousilahti P. The effects of physical activity and body mass index on cardiovascular, cancer and all-cause mortality among 47212 middle-aged Finnish men and women. Int J Obes. 2005;29(8):894-902.

150. Rahman I, Bellavia A, Wolk A, Orsini N. Physical activity and heart failure risk in a prospective study of men. JACC Heart Fail. 2015;3(9):681-687.

151. Bennett $\mathrm{D}$, Bennett $\mathrm{DA}, \mathrm{Du} \mathrm{H}$, et al. Association of physical activity with risk of major cardiovascular diseases in Chinese men and women. JAMA Cardiol. 2017;2(12):1349-1358.

152. Gebel K, Ding D, Chey T, Stamatakis E, Brown WJ, Bauman AE. Effect of moderate to vigorous physical activity on all-cause mortality in middle-aged and older Australians. JAMA Intern Med. 2015;175(6):970-977.

153. O'Donovan G, Lee IM, Hamer M, Stamatakis E. Association of "weekend warrior" and other leisure time physical activity patterns with risks for all-cause, cardiovascular disease, and cancer mortality. JAMA Intern Med.

2017;177(3):335-342.

154. Keum N, Bao Y, Smith-Warner SA, et al. Association of physical activity by type and intensity with digestive system cancer risk. JAMA Oncol. 2016;2(9):1146-1153.

155. Hayasaka S, Shibata Y, Ishikawa S, et al. Physical activity and all-cause mortality in Japan: the Jichi Medical School (JMS) Cohort Study. J Epidemiol. 2009;19(1):24-27.

156. Mok Y, Won S, Kimm H, Nam C, Ohrr H, Jee SH. Physical activity level and risk of death: the Severance cohort study. J Epidemiol. 2012;22(6):494-500.

157. Liu Y, Wen W, Gao YT, et al. Level of moderate-intensity leisure-time physical activity and reduced mortality in middle-aged and elderly Chinese. J Epidemio/ Community Health. 2018;72(1):13-20.

158. Paganini-Hill A, Perez Barreto M. Stroke risk in older men and women: aspirin, estrogen, exercise, vitamins, and other factors. J Gender-Specif Med. 2001;4(2):18-28.

159. Baumeister SE, Schlesinger S, Aleksandrova K, et al. Association of physical activity and risk of hepatobiliary cancers: a multinational cohort study. J Hepatol. 2018;70(5):885-892.

160. Borch KB, Lund E, Braaten T, Weiderpass E. Physical activity and the risk of postmenopausal breast cancer - the Norwegian Women and Cancer Study. J Negat Results Biomed. 2014;13:3.

161. Richard A, Martin B, Wanner M, Eichholzer M, Rohrmann S. Effects of leisure-time and occupational physical activity on total mortality risk in NHANES III according to sex, ethnicity, central obesity, and age. J Phys Act Health. 2015;12(2):184-192. 
medRxiv preprint doi: https://doi.org/10.1101/2022.03.02.22271753; this version posted March 2, 2022. The copyright holder for this preprint (which was not certified by peer review) is the author/funder, who has granted medRxiv a license to display the preprint in perpetuity.

It is made available under a CC-BY 4.0 International license .

162. Rhee CW, Kim JY, Park BJ, Li ZM, Ahn YO. Impact of individual and combined health behaviors on all causes of premature mortality among middle aged men in Korea: the Seoul male cohort study. J Prev Med Public Health. 2012;45(1):14-20.

163. Hotaling JM, Walsh TJ, Macleod LC, et al. Erectile dysfunction is not independently associated with cardiovascular death: data from the Vitamins and Lifestyle (VITAL) Study. J Sex Med. 2012;9(8):2104-2110.

164. Chomistek AK, Manson JE, Stefanick ML, et al. Relationship of sedentary behavior and physical activity to incident cardiovascular disease: results from the Women's Health Initiative. JACC. 2013;61(23):2346-54.

165. Lv J, Yu C, Guo Y, et al. Adherence to healthy lifestyle and cardiovascular diseases in the Chinese population. J Am Coll Cardiol. 2017;69(9):1116-1125.

166. Pandey A, LaMonte $M$, Klein L, et al. Relationship between physical activity, body mass index, and risk of heart failure. J Am Coll Cardiol. 2017;69(9):1129-1142.

167. Chomistek AK, Cook NR, Rimm EB, Ridker PM, Buring JE, Lee IM. Physical activity and incident cardiovascular disease in women: is the relation modified by level of global cardiovascular risk? J Am Heart Assoc. 2018;7(12):e008234.

168. Jeong HG, Kim DY, Kang DW, et al. Physical activity frequency and the risk of stroke: a nationwide cohort study in Korea. J Am Heart Assoc. 2017;6(9):e005671.

169. Shiroma EJ, Sesso HD, Moorthy MV, Buring JE, Lee IM. Do moderate-intensity and vigorous-intensity physical activities reduce mortality rates to the same extent? J Am Heart Assoc. 2014;3(5):e000802.

170. Chiuve SE, Fung TT, Rexrode KM, et al. Adherence to a low-risk, healthy lifestyle and risk of sudden cardiac death among women. JAMA. 2011;306(1):62-69.

171. Hu FB, Stampfer MJ, Colditz GA, et al. Physical activity and risk of stroke in women. JAMA. 2000;283(22):29612967.

172. Kujala UM, Kaprio J, Sarna S, Koskenvuo M. Relationship of leisure-time physical activity and mortality: the Finnish Twin Cohort. JAMA. 1998;279(6):440-444.

173. Kushi LH, Fee RM, Folsom AR, Mink PJ, Anderson KE, Sellers TA. Physical activity and mortality in postmenopausal women. JAMA. 1997;277(16):1287-1292.

174. McTiernan A, Kooperberg C, White E, et al. Recreational physical activity and the risk of breast cancer in postmenopausal women: the Women's Health Initiative Cohort Study. JAMA. 2003;290(10):1331-1336.

175. Tanasescu M, Leitzmann MF, Rimm EB, Willett WC, Stampfer MJ, Hu FB. Exercise type and intensity in relation to coronary heart disease in men. JAMA. 2002;288(16):1994-2000.

176. Maruti SS, Willett WC, Feskanich D, Rosner B, Colditz GA. A prospective study of age-specific physical activity and premenopausal breast cancer. J Nat/ Cancer Inst. 2008;100(10):728-737.

177. Paganini-Hill A, Kawas $\mathrm{CH}$, Corrada MM. Activities and mortality in the elderly: the Leisure World cohort study. $J$ Gerontol Ser A Biol Sci Med Sci. 2011;66 A(5):559-567.

178. Lear SA, Hu W, Rangarajan S, et al. The effect of physical activity on mortality and cardiovascular disease in 130]000 people from 17 high-income, middle-income, and low-income countries: the PURE study. Lancet. 2017;390(10113):2643-2654.

179. Wen CP, Wai JP, Tsai MK, et al. Minimum amount of physical activity for reduced mortality and extended life expectancy: a prospective cohort study. Lancet. 2011;378(9798):1244-53.

180. Artero EG, España-Romero V, Lee DC, et al. Ideal cardiovascular health and mortality: Aerobics Center Longitudinal Study. Mayo Clin Proc. 2012;87(10):944-952.

181. Lee JY, Ryu S, Cheong E, Sung KC. Association of physical activity and inflammation with all-cause, cardiovascularrelated, and cancer-related mortality. Mayo Clin Proc. 2016;91(12):1706-1716.

182. Schmid D, Behrens G, Matthews CE, Leitzmann MF. Physical activity and risk of colon cancer in diabetic and nondiabetic US adults. Mayo Clin Proc. 2016;91(12):1693-1705.

183. McKenzie F, Biessy C, Ferrari P, et al. Healthy lifestyle and risk of cancer in the European Prospective Investigation into Cancer and Nutrition cohort study. Medicine. 2016;95(16):e2850. 
medRxiv preprint doi: https://doi.org/10.1101/2022.03.02.22271753; this version posted March 2, 2022. The copyright holder for this preprint (which was not certified by peer review) is the author/funder, who has granted medRxiv a license to display the preprint in perpetuity.

It is made available under a CC-BY 4.0 International license .

184. Bell EJ, Lutsey PL, Windham BG, Folsom AR. Physical activity and cardiovascular disease in African Americans in atherosclerosis risk in communities. Med Sci Sports Exerc. 2013;45(5):901-907.

185. Chomistek AK, Cook NR, Flint AJ, Rimm EB. Vigorous-intensity leisure-time physical activity and risk of major chronic disease in men. Med Sci Sports Exerc. 2012;44(10):1898-1905.

186. Lee DY, Rhee EJ, Cho JH, et al. Appropriate amount of regular exercise is associated with a reduced mortality risk. Med Sci Sport Exerc. 2018;50(12):2451-2458.

187. Lee IM, Paffenbarger RS, Jr. Physical activity and its relation to cancer risk: a prospective study of college alumni. Med Sci Sport Exerc. 1994;26(7):831-836.

188. Autenrieth CS, Evenson KR, Yatsuya H, Shahar E, Baggett C, Rosamond WD. Association between physical activity and risk of stroke subtypes: the atherosclerosis risk in communities study. Neuroepidemiology. 2013;40(2):109-16.

189. Myint PK, Luben RN, Wareham NJ, et al. Combined work and leisure physical activity and risk of stroke in men and women in the European Prospective Investigation into Cancer-Norfolk prospective population study. Neuroepidemiology. 2006;27(3):122-129.

190. Manson JE, Hu FB, Rich-Edwards JW, et al. A prospective study of walking as compared with vigorous exercise in the prevention of coronary heart disease in women. New Engl J Med. 1999;341(9):650-658.

191. Thune I, Brenn T, Lund E, Gaard M. Physical activity and the risk of breast cancer. New Engl J Med. 1997;336(18):1269-1275.

192. Folsom AR, Demissie Z, Harnack L. Glycemic index, glycemic load, and incidence of endometrial cancer: the lowa Women's Health Study. Nutr Cancer. 2003;46(2):119-124.

193. Holme I, Tonstad S. Increased predictive ability of BMI but not other risk factors with time in men: 39-year followup of total mortality in the Oslo study. Obes Facts. 2014;7(5):311-321.

194. Sieverdes JC, Sui X, Lee D, Lee I, Hooker SP, Blair SN. Independent and joint associations of physical activity and fitness on stroke in men. Phys Sportsmed. 2011;39(2):119-126.

195. Cook MB, Matthews CE, Gunja MZ, Abid Z, Freedman ND, Abnet CC. Physical activity and sedentary behavior in relation to esophageal and gastric cancers in the NIH-AARP Cohort. PLOS One. 2013;8(12):e84805.

196. Holtermann A, Marott JL, Gyntelberg F, et al. Does the benefit on survival from leisure time physical activity depend on physical activity at work? A prospective cohort study. PLOS One. 2013;8(1):e54548.

197. Park S, Nam BH, Yang HR, et al. Individualized risk prediction model for lung cancer in Korean men. PLoS One. 2013;8(2):e54823.

198. Rangul V, Sund ER, Mork PJ, Re OD, Bauman A. The associations of sitting time and physical activity on total and site-specific cancer incidence: Results from the HUNT study, Norway. PLoS One. 2018;13(10):e0206015.

199. Saevereid HA, Schnohr P, Prescott E. Speed and duration of walking and other leisure time physical activity and the risk of heart failure: a prospective cohort study from the Copenhagen City Heart Study. PLoS One. 2014;9(3):e89909.

200. Williams PT. Dose-response relationship of physical activity to premature and total all-cause and cardiovascular disease mortality in walkers. PLoS One. 2013;8(11):e78777.

201. Alvarez-Alvarez I, Zazpe I, Pérez de Rojas J, et al. Mediterranean diet, physical activity and their combined effect on all-cause mortality: the Seguimiento Universidad de Navarra (SUN) cohort. Prev Med. 2018;106:45-52.

202. Gero K, Iso H, Kitamura A, Yamagishi K, Yatsuya H, Tamakoshi A. Cardiovascular disease mortality in relation to physical activity during adolescence and adulthood in Japan: does school-based sport club participation matter? Prev Med. 2018;113:102-108.

203. Renninger $M$, Lochen ML, Ekelund $U$, et al. The independent and joint associations of physical activity and body mass index with myocardial infarction: The Tromso Study. Prev Med. 2018;116:94-98.

204. Wanner M, Tarnutzer S, Martin BW, et al. Impact of different domains of physical activity on cause-specific mortality: a longitudinal study. Prev Med. 2014;62:89-95.

205. Wu CY, Hu HY, Chou YC, Huang N, Chou YJ, Li CP. The association of physical activity with all-cause, cardiovascular, and cancer mortalities among older adults. Prev Med. 2015;72:23-29. 
medRxiv preprint doi: https://doi.org/10.1101/2022.03.02.22271753; this version posted March 2, 2022. The copyright holder for this preprint (which was not certified by peer review) is the author/funder, who has granted medRxiv a license to display the preprint in perpetuity.

It is made available under a CC-BY 4.0 International license .

206. Hillsdon M, Thorogood M, Murphy M, Jones L. Can a simple measure of vigorous physical activity predict future mortality? Results from the OXCHECK study. Public Health Nutr. 2004;7(4):557-562.

207. Carlsson S, Andersson T, Ahlbom A, Wolk A. Low physical activity and mortality in women: baseline lifestyle and health as alternative explanations. Scand J Public Health. 2006;34(5):480-487.

208. Schnohr P, Grønbæk M, Petersen L, ia Sørensen T, Ole Hein H. Physical activity in leisure-time and risk of cancer: 14-year follow-up of 28,000 Danish men and women. Scand J Public Health. 2005;33(4):244-249.

209. Ou SM, Chen YT, Shih CJ, Tarng DC. Impact of physical activity on the association between lipid profiles and mortality among older people. Sci Rep. 2017;7(1):8399.

210. Zhou Y, Zhang R, Liu Y, et al. Association of regular physical activity with total and cause-specific mortality among middle-aged and older Chinese: a prospective cohort study. Sci Rep. 2017;7:39939.

211. Hu G, Sarti C, Jousilahti P, Silventoinen K, Barengo NC, Tuomilehto J. Leisure time, occupational, and commuting physical activity and the risk of stroke. Stroke. 2005;36(9):1994-1999.

212. Huerta JM, Chirlaque MD, Tormo MJ, et al. Physical activity and risk of cerebrovascular disease in the European Prospective Investigation into Cancer and Nutrition-Spain study. Stroke. 2013;44(1):111-118.

213. Lee IM, Paffenbarger Jr RS. Physical activity and stroke incidence: the Harvard Alumni Health Study. Stroke. 1998;29(10):2049-2054.

214. McDonnell MN, Hillier SL, Hooker SP, Le A, Judd SE, Howard VJ. Physical activity frequency and risk of incident stroke in a national US study of blacks and whites. Stroke. 2013;44(9):2519-24.

215. Rist PM, Lee IM, Kase CS, Michael Gaziano J, Kurth T. Physical activity and functional outcomes from cerebral vascular events in men. Stroke. 2011;42(12):3352-3356.

216. Tikk K, Sookthai D, Monni S, et al. Primary preventive potential for stroke by avoidance of major lifestyle risk factors: the European Prospective Investigation into Cancer and Nutrition-Heidelberg cohort. Stroke. 2014;45(7):20412046.

217. Kunzmann AT, Mallon KP, Hunter RF, et al. Physical activity, sedentary behaviour and risk of oesophago-gastric cancer: a prospective cohort study within UK Biobank. United European Gastroenterol J. 2018;6(8):1144-1154.

218. Grotta A, Bottai M, Adami HO, et al. Physical activity and body mass index as predictors of prostate cancer risk. World J Urol. 2015;33(10):1495-1502.

219. Wahid A, Manek N, Nichols M, et al. Quantifying the association between physical activity and cardiovascular disease and diabetes: a systematic review and meta-analysis. J Am Heart Assoc. 2016;5(9):e002495.

220. Cheng W, Zhang Z, Cheng W, Yang C, Diao L, Liu W. Associations of leisure-time physical activity with cardiovascular mortality: a systematic review and meta-analysis of 44 prospective cohort studies. Eur J Prev Cardiol. 2018;25(17):1864-1872.

221. Golubic R, May AM, Benjaminsen Borch K, et al. Validity of electronically administered Recent Physical Activity Questionnaire (RPAQ) in ten European countries. PLoS One. 2014;9(3):e92829.

222. Geidl W, Schlesinger S, Mino E, Miranda L, Pfeifer K. Dose-response relationship between physical activity and mortality in adults with noncommunicable diseases: a systematic review and meta-analysis of prospective observational studies. Int J Behav Nutr Phys Act. 2020;17(1):109.

223. Strain T, Wijndaele K, Dempsey PC, et al. Wearable-device-measu red physical activity and future health risk. Nat Med. 2020;26(9):1385-1391.

224. Strain T, Wijndaele K, Sharp SJ, Dempsey PC, Wareham N, Brage S. Impact of follow-up time and analytical approaches to account for reverse causality on the association between physical activity and health outcomes in UK Biobank. Int J Epidemiol. 2020;49(1):162-172.

225. Lee DH, Rezende LFM, Ferrari G, et al. Physical activity and all-cause and cause-specific mortality: assessing the impact of reverse causation and measurement error in two large prospective cohorts. Eur J Epidemiol. 2021;36(3):275285.

226. Mok A, Khaw KT, Luben R, Wareham N, Brage S. Physical activity trajectories and mortality: population based cohort study. BMJ. 2019;365:12323. 
medRxiv preprint doi: https://doi.org/10.1101/2022.03.02.22271753; this version posted March 2, 2022. The copyright holder for this preprint (which was not certified by peer review) is the author/funder, who has granted medRxiv a license to display the preprint in perpetuity.

It is made available under a CC-BY 4.0 International license .

227. Ekelund U, Tarp J, Steene-Johannessen J, et al. Dose-response associations between accelerometry measured physical activity and sedentary time and all cause mortality: systematic review and harmonised meta-analysis. BMJ. 2019;366:14570.

228. Troiano RP, McClain JJ, Brychta RJ, Chen KY. Evolution of accelerometer methods for physical activity research. Br J Sports Med. 2014;48(13):1019-23. 